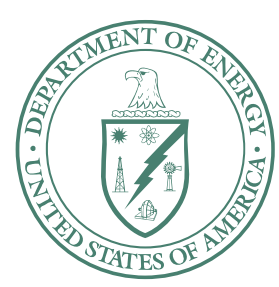

U.S. Department of Energy

Idaho Operations Office

\title{
Characterization Plan for Soils Around Drain Line PLA-100115
}

May 2006 
DOE/ID-11260

Revision 1

Project No. 24782

\section{Characterization Plan for Soils Around Drain Line PLA-100115}

May 2006

Prepared for the U.S. Department of Energy DOE Idaho Operations Office 



\begin{abstract}
This Characterization Plan supports the Hazardous Waste Management Act/Resource Conservation and Recovery Act (HWMA/RCRA) closure of soils that may have been contaminated by releases from drain line PLA-100115, located within Idaho Nuclear Technology and Engineering Center at the Idaho National Laboratory Site. The requirement to address the closure of soils contaminated by a potential release from this line in a characterization plan was identified in the "HWMA/RCRA Less Than 90-day Generator Closure Report for the VES-SFE-126.” This Characterization Plan provides information about sampling design, analyses required, and sample collecting and handling procedures. This document is to be used in conjunction with the current revision of the Quality Assurance Project Plan for Waste Area Groups 1, 2, 3, 4, 5, 6, 7, 10, and Deactivation, Decontamination, and Decommissioning (DOE-ID 2004). Together, these two documents constitute the sampling and analysis plan for the HWMA/RCRA closure of soils derived from suspected releases from PLA-100115, which runs from under the south decontamination pad within CPP-603 to its connection with PLA-100116 near VES-SFE-20.

Because this line carried waste that consisted of Comprehensive Environmental Response, Compensation, and Liability Act (CERCLA) hazardous substances (e.g., radionuclides) in addition to HWMA-regulated constituents, this plan provides for sampling constituents to support preparation of a CERCLA new site identification form for evaluation by the State of Idaho, Environmental Protection Agency, and the Department of Energy in accordance with the Federal Facility Agreement and Consent Order.
\end{abstract}




\section{CONTENTS}

ABSTRACT

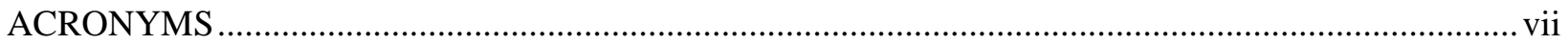

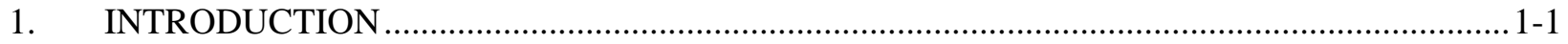

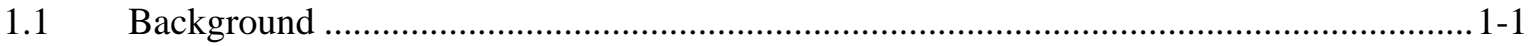

1.1.1 Decontamination Pad and PLA-100115 Line Description................................1-4

1.1.2 Decontamination Drain Riser Video Inspection ............................................ 1-5

1.1.3 Investigative Characterization of Soil Around Line PLA-100115 Outside

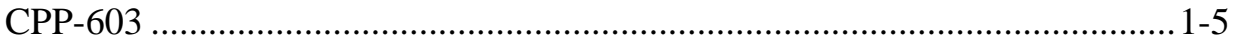

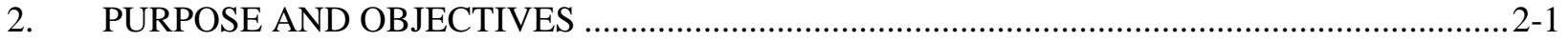

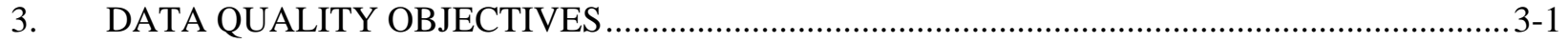

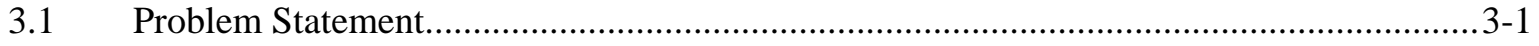

3.2 Principal Study Questions and Decision Statements ..................................................... 3-1

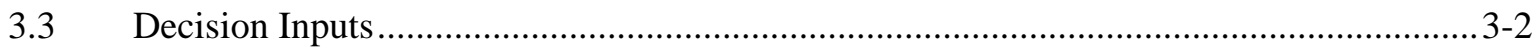

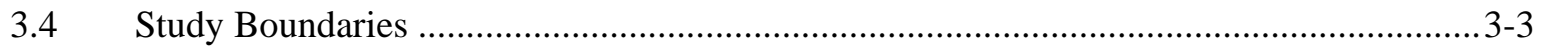

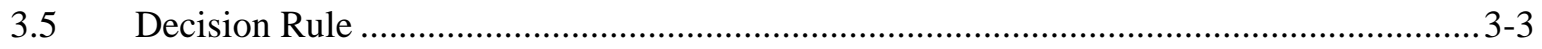

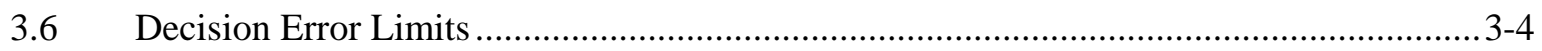

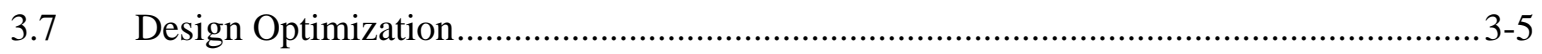

4. SAMPLING and INVESTIGATION APPROACH ...................................................................

4.1 Pipeline Integrity Test and Soil Sampling ............................................................ 4-1

4.1.1 Pipeline Integrity Test Method................................................................ $4-1$

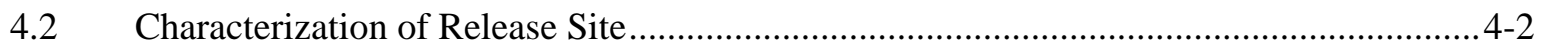

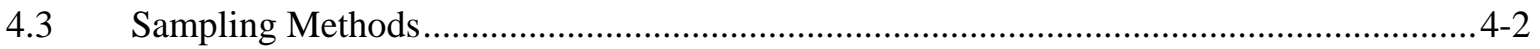

4.3.1 Soil Sampling Procedures …..................................................................... $\quad$-4

4.4 Quality Assurance Objectives ................................................................................ 4-8

4.4.1 Project Quality Objectives ......................................................................... 4-8

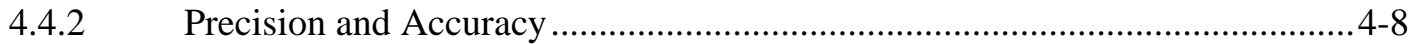

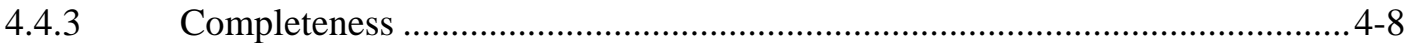

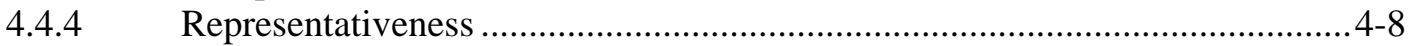

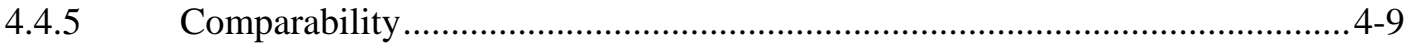




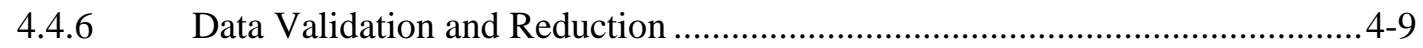

4.4.7 Quality Assurance Objectives for Measurement ............................................ 4-9

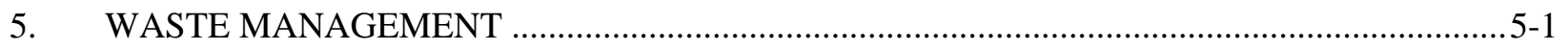

6. DOCUMENT MANAGEMENT AND SAMPLE CONTROL …........................................... 6-1

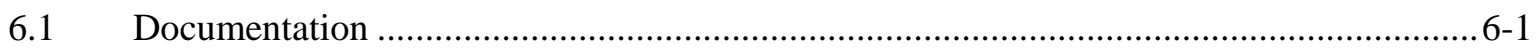

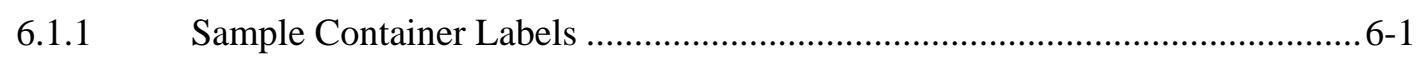

6.1.2 Field Guidance Form...................................................................................... 6-1

6.1.3 Field Logbook ....................................................................................... 6-1

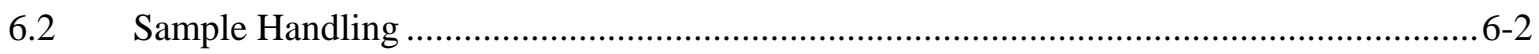

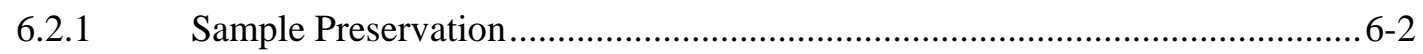

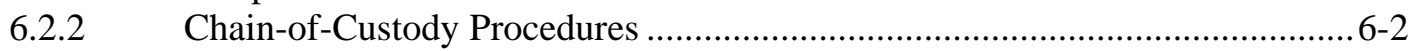

6.2.3 Transportation of Samples ................................................................. 6-2

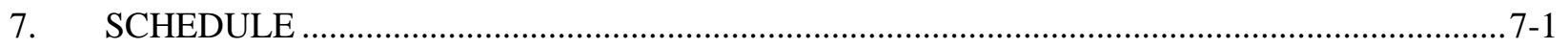

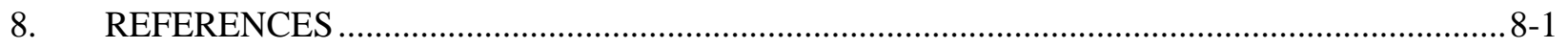

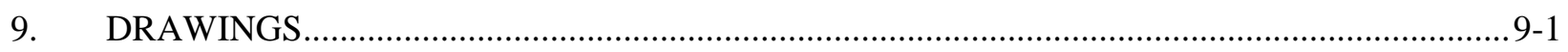

Appendix A—HWMA/RCRA Closure Risk Assessment Methodology for Environmental Media ......... A-1

\section{FIGURES}

1-1. Location of the Idaho National Laboratory Site .................................................................... 1-2

1-2. Flow path for use of soil data collected during closure of the 90-day SFE-126 system.................1-3

1-3. Illustration depicting the location of the PLA-100115 drain line .............................................. 1-3

4-1. Isolation locations (A, B, C) for PLA-100115 drain line integrity pressure test.......................... 4-2

4-2. Sample location through the drain line at the decontamination pad inside CPP-603.....................4-3

\section{TABLES}

2-1. Contaminants of concern to be analyzed for in soil samples....................................................2-2

4-2. Analytical methods for constituents ................................................................................. $4-7$ 


\section{ACRONYMS}

AA alternative actions

CERCLA Comprehensive Environmental Response, Compensation, and Liability Act

COC contaminant of concern

CP Characterization Plan

DEQ Department of Environmental Quality

DOE Department of Energy

EPA Environmental Protection Agency

HWMA Hazardous Waste Management Act

ICP Idaho Cleanup Project

INL Idaho National Laboratory

INTEC Idaho Nuclear Technology and Engineering Center

NSIF New Site Identification Form

PRG preliminary remediation goal

PSQ principal study questions

QA quality assurance

QAPjP Quality Assurance Project Plan

QC quality control

RCRA Resource Conservation and Recovery Act

RfD reference dose

SF $\quad$ slope factor

SVOC semivolatile organic compounds

TAL target analyte list

UCL upper confidence level

VOC volatile organic compounds 


\section{Characterization Plan for Soils Around Drain Line PLA-100115}

\section{INTRODUCTION}

In accordance with the HWMA/RCRA Less Than 90-day Generator Closure Report for the VES-SFE-126 (INEEL 2000), the U.S. Department of Energy (DOE) submits this Characterization Plan (CP). VES-SFE-126 is a 3,400-gal liquid collection tank located east of CPP-603 within the Idaho Nuclear Technology and Engineering Center (INTEC) facility at the Idaho National Laboratory (INL) Site (see Figure 1-1). Until 1989, this tank received hazardous waste discharges from decontamination activities performed in CPP-603 and accumulated these wastes for 90 days or less. ${ }^{\text {a }}$ After 1989, the tank accepted non-hazardous wastewater prior to the closure activities. Releases are known to have occurred under the south decontamination pad in Building CPP-603 from the 3-1/2-in. PLA-100115 drain line (hereafter referred to as PLA-100115). This CP provides guidance for the collection of soil samples near the release site of drain line PLA-100115 within CPP-603 and also provides guidance for identifying other potential release sites along the drain line outside of Building CPP-603. Information gathered during this characterization effort will be used to support the closure of contaminated soils under the Hazardous Waste Management Act/Resource Conservation and Recovery Act (HWMA/RCRA) and the preparation of a Comprehensive Environmental Response, Compensation, and Liability Act (CERCLA) new site identification form (NSIF) for contaminated soils. HWMA/RCRA closure of contaminated soils will be coordinated with the CERCLA process illustrated in Figure 1-2.

This CP is implemented with the latest revision of the Quality Assurance Project Plan for Waste Area Groups 1, 2, 3, 4, 5, 6, 7, 10, and Deactivation, Decontamination, and Decommissioning (QAPjP) (DOE-ID 2004), which provides guidance for sampling, quality assurance (QA), quality control (QC), analytical procedures, and data management. Together, the QAPjP and this CP constitute the sampling and analysis plan. Unless otherwise described in this CP, the QAPjP describes the objectives and QA/QC protocols that will be used to ensure reliable data results. Use of this CP will help ensure that data are scientifically valid, defensible, and of known and acceptable quality, while use of the QAPjP will ensure that the data generated are suitable for their intended purposes.

\subsection{Background}

The soils surrounding the PLA-100115 drain line are currently included in the HWMA/RCRA Less Than 90-day Generator Closure Report for the VES-SFE-126 (INEEL 2000). As identified in the 90-day Generator Closure Report for VES-SFE-126, releases of waste from this drain line are known to have occurred under the south decontamination pad in CPP-603 where 3 1/2-in. diameter PLA-100115 originates (approximately $28 \mathrm{ft}$ west of the CPP-603 east wall, see Figure 1-3).

The HWMA/RCRA Closure Report (INEEL 2000) identifies that, in order to complete the closure of the VES-SFE-126 tank system, a characterization plan for soils associated with this drain line will be prepared during deactivation of CPP-603, and soil characterization efforts will be implemented following removal of water and sludge from CPP-603 basins. Following Idaho Department of Environmental Quality (DEQ) approval of the CP, characterization will be performed and the results presented to DEQ in a summary report, according to the schedule presented in Section 7. This summary report is anticipated to provide the required documentation for closure of the soils and integration with CERCLA, using the flow path identified in Figure 1-2.

a. A plot plan/figure showing INTEC and building CPP-603 is not included in this report per DOE O 471.3, "Identifying and Protecting Official Use Only Information.” 

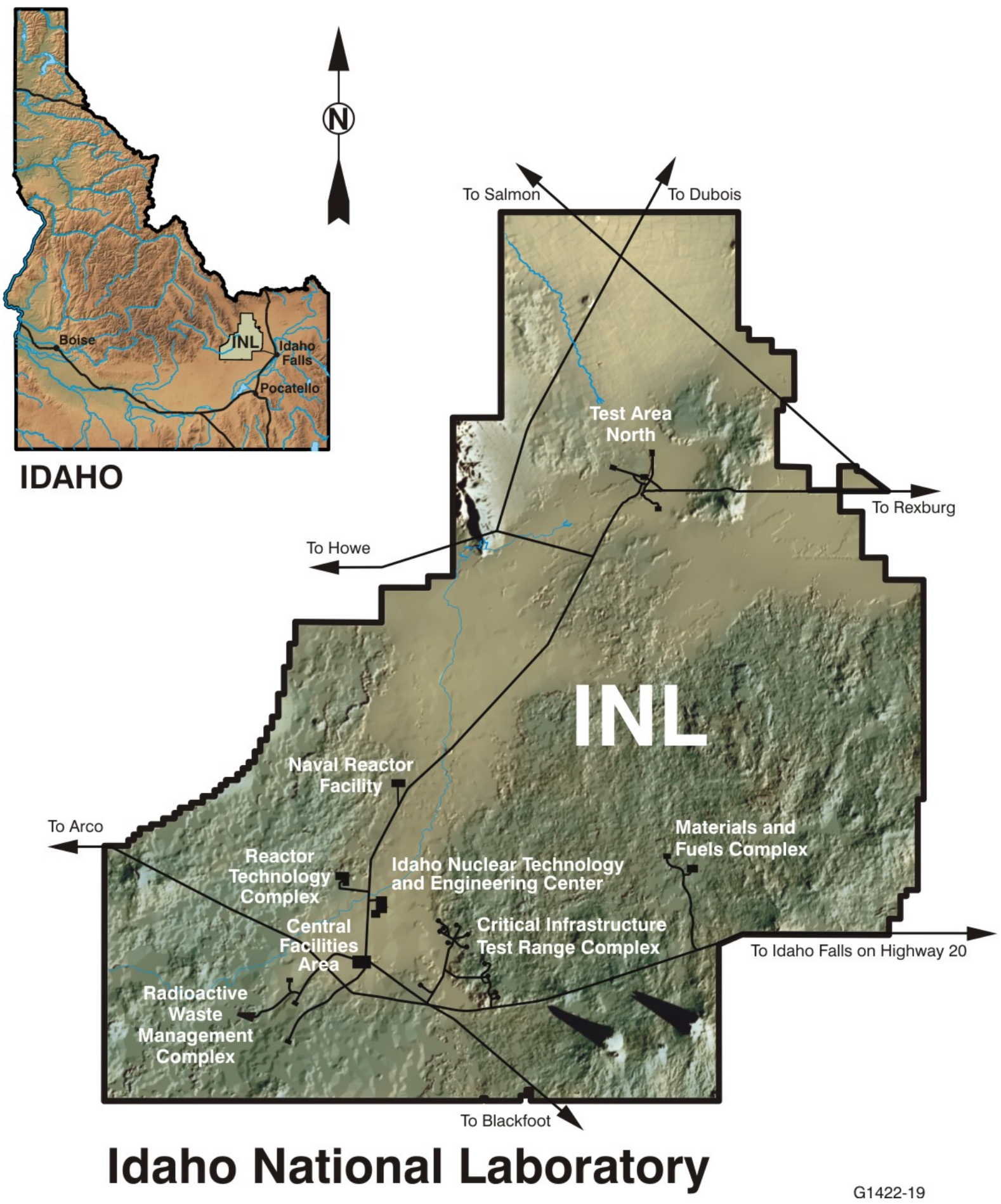

Figure 1-1. Location of the Idaho National Laboratory Site. 

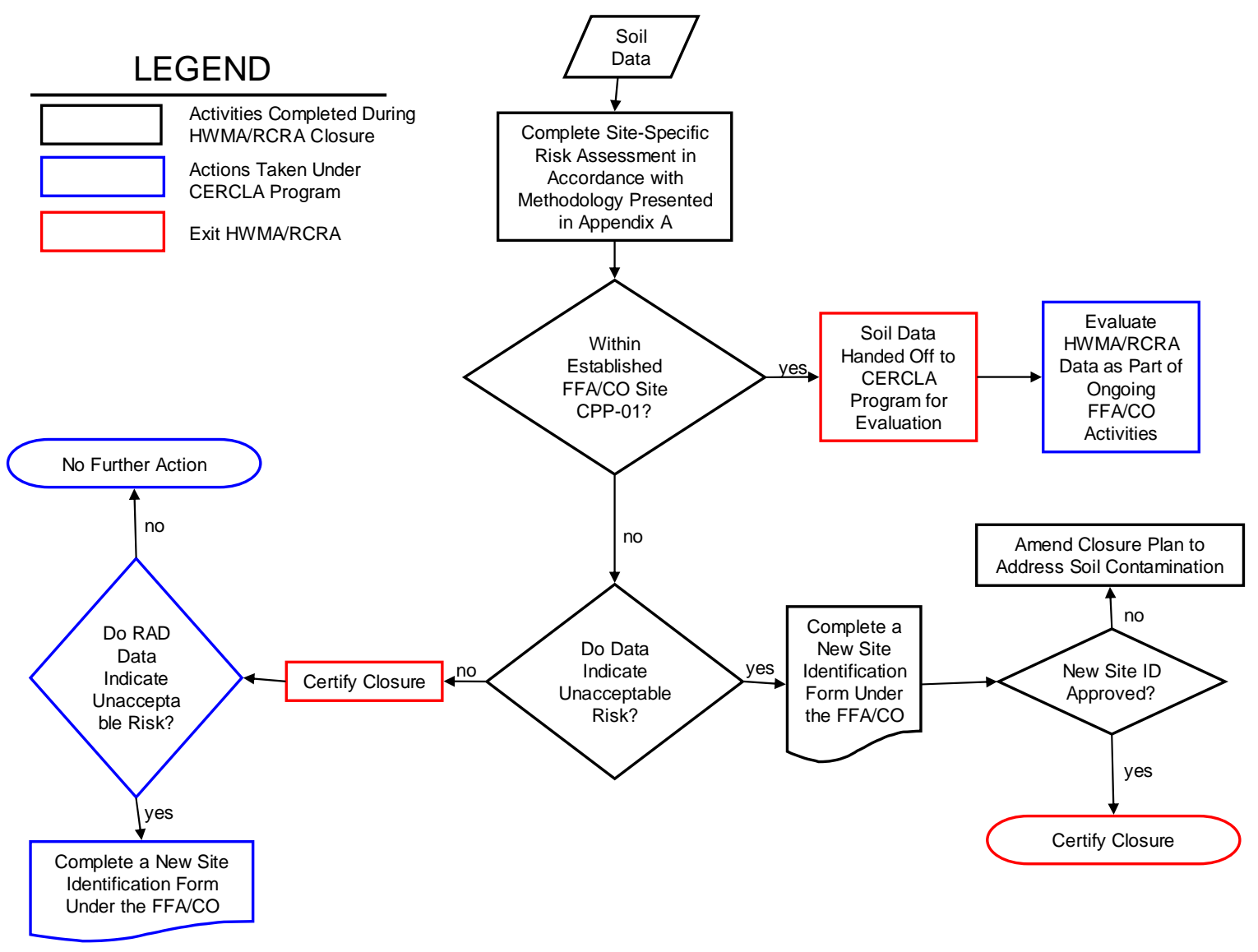

Figure 1-2. Flow path for use of soil data collected during closure of the 90-day SFE-126 system.

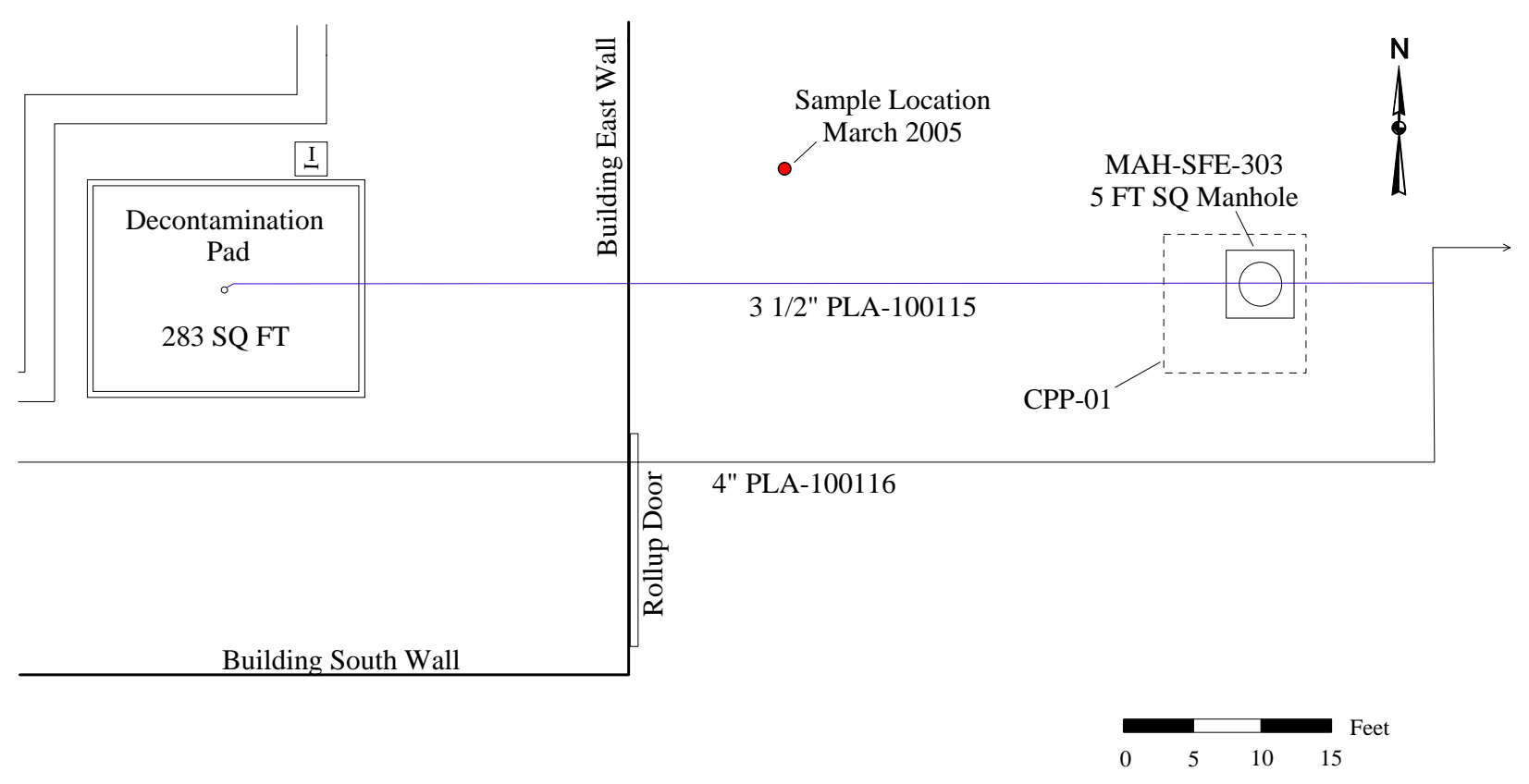

Figure 1-3. Illustration depicting the location of the PLA-100115 drain line. 


\subsubsection{Decontamination Pad and PLA-100115 Line Description}

The CPP-603 south decontamination pad is a $283-\mathrm{ft}^{2}$ area with outer measurements of $20 \mathrm{ft}$ by $15 \mathrm{ft}-11 \mathrm{in}$. Constructed in the mid 1950s, the south decontamination pad (also referred to as the wash basin or the cask washing area) is made from poured concrete with 6-in.-tall by 6-in.-wide concrete curbs on the south and east sides. The north and west sides have 6-in.-high curbs with widths that range from $2-1 / 2$ to 3-1/2 ft and slope inward toward the center of the pad. The pad floor is level east to west but the north and southern halves slope slightly inward toward the center floor drain. The concrete floor is a minimum of $1 \mathrm{ft}$ thick and reinforced with number 6 (3/4-in.-diameter) rebar placed $12 \mathrm{in}$. apart each way. When constructed, the pad was lined with aluminum sheeting which has since been replaced with stainless steel sheeting. In addition, the pad was once partially surrounded by a 10 -ft-tall canvas curtain which was replaced by 4 -ft-tall stainless steel walls.

The PLA-100115 line begins in the center of the south decontamination pad at a floor drain which consists of a stainless steel strainer fitting that sits over a 6-in.-diameter cast iron bell and spigot pipe. The iron pipe extends downward approximately $6 \mathrm{ft}$ below grade where a 90 degree turn was made to a horizontal pipe that extends approximately $1 \mathrm{ft}$ to the northeast. From this point, the pipe makes a 45 degree turn and continues directly east. The pipe diameter is reduced from 6 in. to 3-1/2-in. past the 90 degree turn where the piping changes from cast iron to stainless steel. After the 45 degree turn, the stainless steel drain line extends east underneath the building foundation, ${ }^{\mathrm{b}}$ through manhole MAH-SFE-303, to the point where it connects to the 4-in. PLA-100116 line approximately $88 \mathrm{ft}$ east of the floor drain (see Figure 1-3). The relationship between the PLA-100115 line and the MAH-SFE-303 manhole is not known. Utility drawings, dating from 1956 to the present, show the PLA-100115 line running through the manhole but having no connection to it.

Manhole MAH-SFE-303 is contained within the southern component of Federal Facility Agreement and Consent Order (FFA/CO) CERCLA soil contamination site CPP-01 (Figure 1-3). This manhole covers a deep dry well (CPP-303) that received supernatant from a vertical settling vault (CPP-301). The supernatant was the result of the settling of backwash slurry filter aid material (diatomaceous earth) from the filter system associated with the Fuel Receiving and Storage Facility activities in CPP-603. The deep dry well reportedly received supernatant from 1951 until 1962. As part of the OU 3-09 Track 2 characterization activities at CPP-01 in 1993, one soil boring was drilled approximately $7 \mathrm{ft}$ from the dry well CPP-303 and continuous soil samples were taken from 0.5 to $10 \mathrm{ft}$ ( 0.15 to $3 \mathrm{~m}$ ) bgs. Sample results showed the presence of the following radiological contaminants:

Am-241, Co-57, Co-60, Cs-137, Eu-152, Eu-154, Eu-155, Sr-90, U-235, and U-238. Of these, levels of both Cs-137 and Sr-90 exceeded the remediation goals as defined by the OU 3-13 Record of Decision. Results for Cs- 137 were as high as $1,800 \mathrm{pCi} / \mathrm{g}$ at a depth from 8 to $10 \mathrm{ft}$ bgs. Results for Sr-90 were as high as $650 \mathrm{pCi} / \mathrm{g}$ at 8 to $10 \mathrm{ft}$ bgs (DOE-ID 2006). Based on these sample results, radiologically-contaminated soil is known to extend radially outward and below ground surface in excess of $10 \mathrm{ft}$. The contaminated soil at FFA/CO site CPP-01 will be excavated and transported to the INL CERCLA Disposal Facility for disposal as per the excavation design and schedule outlined in the Operable Unit 3-13, Group 3, Other Surface Soils Remediation Sets 4-6 (Phase II) Remedial Design/Remedial Action Work Plan (DOE-ID 2006). The planned excavation is expected to include the area that contains the connection between the PLA-100115 and PLA-100116 drain lines due to the necessary sloping of the excavation and probable chasing of contaminated soil.

b. Construction drawings indicate that the concrete foundation for CPP-603 extends $5 \mathrm{ft}$ bgs while the PLA-100115 drain line is approximately 6-1/2 ft bgs at the buildings foundation. 
The south decontamination pad is located in the southeast corner of the CPP-603 complex near a tall 16-ft-wide rollup truck bay door. Partial building walls are located on the north and west sides but the south and east sides are free of building substructures (see Figure 1-3). In addition, 18-20 ft of unobstructed space exists over the pad. The pad area is currently congested with eight large waste containers and shielding that is being used in support of other CPP-603 activities. This material must be removed before any characterization activities can be performed at the pad.

\subsubsection{Decontamination Drain Riser Video Inspection}

In June 1999, a video camera was lowered into the drain line beneath the south decontamination pad. As viewded by the camera, the drain riser (6-in.-diameter cast iron bell and spigot pipe) extended approximately 5-6 ft down (this depth is confirmed by original design drawings) and its interior surface was extensively coated with debris. At the bottom of the riser, a pipe elbow was not present and the riser terminated above a bell-shaped void that contained debris. Visible at the bottom of the void and to the side were several inches of the horizontal drain line. Just inside the entrance to the horizontal drain pipe was a mass of accumulated material that would impair partial flows from draining out this void.

While the video camera was at the bottom of the drain riser, one pint of water, containing dye, was added just outside the horizontal drain pipe. ${ }^{\mathrm{C}}$ The blockage just inside the horizontal drain pipe prevented this water from entering and directed it to the void beneath the drain riser. The video inspection indicated degradation of the drain system at the base of the riser had occurred, but the camera was unable to travel past this 90-degree angle under the CPP-603 building to further inspect the line. Therefore, releases to the environment directly below the vertical riser appear to have occurred (under the CPP-603 building), however the integrity of the horizontal drain pipe beyond this point is unknown. Once the condition of the pipe below the floor drain was determined, immediate corrective actions were taken which included the notification of the State of Idaho, the implementation of administrative controls to stop any further discharges to the drain line, and the installation of a new drain line plug in May 2000 (INEEL 2000).

\subsubsection{Investigative Characterization of Soil Around Line PLA-100115 Outside CPP-603}

In support of the Department of Energy Idaho Operations Office commitment to conduct soil sampling and analysis around the PLA-100115 drain line outside of Building CPP-603, as identified in Section 4.1 of the CERCLA Action Memorandum for the Non-Time Critical Removal Action at the CPP-603A Basins, Idaho Nuclear Technology and Engineering Center (DOE-NE-ID 2005a), a CERCLA investigative sampling activity was performed in March 2005.

Soil samples were collected vertically from a location near CPP-603 in accordance with the Field Sampling Plan (DOE-ID 2005b) (see Figure 1-3). Samples were collected from a location as close as possible to PLA-100115 (8 ft north) and Building CPP-603 (12 ft east), without affecting existing utilities at depths from $6 \mathrm{ft}$ bgs to refusal at the basalt interface. The sample location was selected to provide information regarding whether contaminants from releases under the building migrated beyond the CPP-603 footprint. At the INL, releases associated with piping typically have been observed to follow a preferential pathway such as along gravels and sands that have minimal restrictions to aqueous flows. Specifically, relative to releases from piping, preferential pathways have been observed to be associated with piping beds of gravels and fines (sands) that were placed in the piping bed to facilitate piping

c. While the 2005 Closure Report say the intent of the 1 pint of water with dye was to perform an integrity evaluation, general calculations estimate that a minimum volume of 29 times this would be required to transport a fraction of the dye from the drain entrance to where it terminates at the 4-in. PLA-100116 pipe connection, assuming ideal conditions (e.g., proper pipe slope, back flow prevention, no pipe blockage, and flush-joints). 
installation and backfill and compaction. In contrast, the undisturbed native soil beneath and adjacent to piping typically has a clay content. Although releases spread through these adjacent soils, the releases typically travel more readily in the piping beds of gravels and sands that are located immediately adjacent to the pipe. As a result, it is preferable to focus sampling activities in the immediate area of piping, if possible.

Analysis of the soil samples collected from this 2005 sampling event showed that radionuclide, metals, VOCs, chlorides, and nitrates analytes sampled for were not present at levels at or above soil risk-based remediation goals (Verwolf 2005). However, insufficient information was obtained to assume a lateral extent of contamination either within or beyond the eastern foundation of CPP-603. 


\section{PURPOSE AND OBJECTIVES}

The objective of this CP is to specify methods for determining the nature and extent of contamination in the soils associated with the PLA-100115 drain line (INEEL 2000). This information will support the characterization and closure of soils along this drain line and complete the HWMA/RCRA closure of the VES-SFE-126 tank system. This CP provides guidance for the collection and analyses of soil samples and for conducting a pressure test to verify integrity of the line outside CPP-603. To accomplish this, the following list of activities will occur:

1. Outside CPP-603: a pressure test will be performed on the PLA-100115 line to determine integrity. If the line passes, the soils surrounding the line will be considered free of releases and no further action will be required. If the line fails the test, the soil above the line will be excavated, the line removed, and the soil beneath the line sampled for COCs (see Table 2-1).

2. Inside CPP-603: soil samples will be collected beneath the south decontamination pad.

According to the 90-day Closure Report inlet line PLA-100116 to VES-SFE-126, including drain line PLA-100115, is considered clean. Since 1989 over 40,000 gallons of non-hazardous waste water has flushed/cleaned the lines. Since this flushing, the PLA-100115 drain line has been isolated from any process via administrative controls. In addition, the isolation has been further enhanced by the installation of a drain plug. Therefore, drain line PLA-100115 posed no risk of additional released to the environment (INEEL 2000) until final closure is determined. If the line can pass a pressure integrity test, it will be considered clean/closed and can be managed under CERCLA as necessary.

Soils near the drain origin beneath the south decontamination pad in CPP-603 known to receive releases from PLA-100115 and will be sampled for the COCs identified below (see Table 2-1). Analysis of these samples will include volatile organic compounds (VOCs), semivolatile organic compounds (SVOCs), and inorganics. This table also identifies CERCLA hazardous substances, such as radiological constituents, that will also be analyzed for in order to support completion of a CERCLA NSIF.

Sample results from soils collected in support of this CP will be presented to the DEQ in a summary report and will include the results of a site-specific risk assessments for HWMA/RCRA constituents, in accordance with the methodology outlined in Appendix A. In accordance with the 90-day Generator Closure Report, closure of the soils will be planned and coordinated during deactivation and decontamination planning and integrated with CERCLA remedial actions. The soil will be remediated in conjunction with WAG-3 remediation activities (INEEL 2000). 
Table 2-1. Contaminants of concern to be analyzed for in soil samples.

\begin{tabular}{|c|c|c|}
\hline \multicolumn{3}{|c|}{ Contaminant of Concern ${ }^{\mathrm{a}, \mathrm{b}}$} \\
\hline Metals & Organics & Radionuclides \\
\hline Aluminum & Bis(2-ethylhexyl) phthalate & Americium-241, -243 \\
\hline Antimony & Butylbenzylphthalate & Cesium-137 \\
\hline Arsenic & Phenanthrene & Cobalt-60 \\
\hline Barium & 1,1,1,2-tetrachloroethane & Curium-244 \\
\hline Cadmium & 1,1,1-trichloroethane & Europium-152, -154, \\
\hline Calcium & 1,1,2-trichloroethane & Tritium \\
\hline Chromium & 1,1-dichloroethane & Iodine-129 \\
\hline Cobalt & 1,1-dichloroethene & Potassium-40 \\
\hline Copper & Acetone & Manganese-54 \\
\hline Iron & Aroclor-1260 & Neptunium-237 \\
\hline Lead & Carbon disulfide & Niobium-95 \\
\hline Magnesium & Chlorobenzene & $\begin{array}{l}\text { Plutonium-238, }-239 / 240 \text {, } \\
-241,-242\end{array}$ \\
\hline Manganese & Chlorodifluoromethane & Strontium-90 \\
\hline Nickel & Chloroethane & Technetium-99 $^{c}$ \\
\hline Potassium & Chloromethane & Uranium-234, -235, -238 \\
\hline Selenium & Ethylbenzene & Zirconium-95 \\
\hline Silver & \multicolumn{2}{|l|}{ Tetrachloroethene } \\
\hline Thallium & \multicolumn{2}{|l|}{ Toluene } \\
\hline Vanadium & \multicolumn{2}{|l|}{ Trichloroethene } \\
\hline Zinc & \multicolumn{2}{|l|}{ Vinyl chloride } \\
\hline \multirow[t]{2}{*}{ Mercury } & \multicolumn{2}{|l|}{ Xylene } \\
\hline & \multicolumn{2}{|c|}{ Freon 22 (chlorodifluoromethane) } \\
\hline \multicolumn{3}{|c|}{$\begin{array}{l}\text { a. Radiological COCs are based on SFE-20 Hot Waste Tank characterization results (PLA-100115 used to drain to this tank) } \\
\text { and soil-based remediation goals from the Operable Unit 3-13 Record of Decision (DOE-ID 1999). }\end{array}$} \\
\hline \multicolumn{3}{|c|}{$\begin{array}{l}\text { b. Metals and organic COCs include HWMA/RCRA-regulated constituents and CERCLA hazardous substances identified } \\
\text { in the HWMA/RCRA Less than 90-day Generator Closure Report for the VES-SFE-126 (INEEL 2000) and the } \\
\text { Characterization Summary Report for Operable Unit 3-13, Group 7, VES-SFE-20 Hot Waste System at INTEC (ICP 2005). }\end{array}$} \\
\hline \multicolumn{3}{|c|}{$\begin{array}{l}\text { c. Although not listed in the Operable Unit 3-13 Record of Decision (DOE-ID 1999), Tc-99 is included on this list as a COC } \\
\text { due to levels found in some wells at INTEC that are above maximum contaminant levels (MCLs). }\end{array}$} \\
\hline
\end{tabular}




\section{DATA QUALITY OBJECTIVES}

The data quality objectives process, which is used to qualitatively and quantitatively specify the objectives for the data collected, was designed as a specific planning tool to establish criteria for defensible decision-making and to facilitate the design of the data acquisition efforts. The data quality objectives process is described in the U.S. Environmental Protection Agency (EPA) document Data Quality Objective Process for Hazardous Waste Site Investigations (EPA 2000). The data quality objectives process includes seven steps, each of which has specific outputs. These steps are outlined in the following sections.

\subsection{Problem Statement}

The problem statement is intended to define the problem so that the focus of the sampling and analysis will be unambiguous.

The problem statement is to determine if line PLA-100115 has been closed in a manner protective of human health and the environment. Soils data will be collected to make this determination. The data are required to evaluate whether soils warrant inclusion within the FFA/CO via the NSIF process (soils outside established FFA/CO sites) or to provide HWMA/RCRA contaminant information to the ICP CERCLA Program for evaluation as part of ongoing and planned remediation activities (soils within the area of impact of FFA/CO Sites). Soil samples will be collected underneath PLA-100115 only if it is demonstrated that the line does not have integrity and the line is removed.

\subsection{Principal Study Questions and Decision Statements}

This step in the data quality objectives process identifies the decisions and actions that will be taken based on the data collected. Principal study questions (PSQs) and alternative actions (AAs) that could result from resolution of the PSQs are developed, and the PSQs and AAs are then combined into decision statements (DSs). The objective of this characterization activity is to answer the PSQs.

The PSQs associated with the problem statement are

1. Are HWMA/RCRA COCs present in soils associated with the release point under the decontamination pad $\mathrm{A}$ in concentrations that pose a risk to human health and the environment?

2. Are HWMA/RCRA COCs present in the soils under PLA-100115 outside of CPP-603 (if piping integrity is not verified and the line is removed) in concentrations that pose a risk to human health and the environment (based on a site-specific risk assessment, Appendix A)? This PSQ only applies to sections of piping where integrity is not confirmed and the line is removed.

The AAs for these PSQs are

PSQ 1:

AA1. If HWMA/RCRA COCs are present at concentrations in the soils under the decontamination pad that pose a risk to human health then a NSIF under the FFA/CO will be completed and submitted to the Agencies.

AA2. IF HWMA/RCRA COCs are not present at concentrations that pose a risk to human health then, then the release point under the decontamination pad A can be considered as not requiring further action for HWMA/RCRA closure. A NSIF will be submitted to the agencies for the release 
under the south decontamination pad whether or not a NSIF is required for the HWMA/RCRA closure. If a NSIF is required for closure, it will include necessary information for the CERCLA COCs. However, if a NSIF is not required under the closure, based on the decision rule below, the NSIF will not address RCRA and will not be a requirement for the closure certification.

PSQ 2:

AA1. If HWMA/RCRA COCs are present in soils beneath PLA-100115 (should integrity not be verified and the line removed) at concentrations that pose a risk to human health, then a NSIF under the FFA/CO will be completed and submitted to the Agencies.

AA2. If HWMA/RCRA COCs are present in the soils underneath PLA-100115 at concentrations that do not pose a risk to human health then no further action will be taken under HWMA/RCRA closure with regard to these soils.

The decision statement that follows from PSQ 1 and its AAs is

Determine whether soil contamination associated with the release site under the south decontamination pad pose a risk to human health (based on risk assessment method described in Appendix A) for the HWMA/RCRA COCs and if necessary, complete a NSIF under the FFA/CO to submit to the Agencies for review and approval.

The decision statement that follows from PSQ 2 and its AAs is

Determine whether the concentration of HWMA/RCRA COCs in the soils beneath PLA-100115, (if the integrity of PLA-100115 is not verified and the line is removed) in concentrations that pose a risk to human health (based on the risk assessment method described in Appendix A), and if necessary, complete a NSIF under the FFA/CO to submit to the Agencies for review and approval.

Because a portion of line PLA-100115 is located within the FFA/CO site CPP-01, if the integrity of the line is not verified and the line removed, the data from soil samples collected beneath the line within this area will be provided to the CERCLA program for evaluation during ongoing and/or planned remedial actions associated with this site.

\subsection{Decision Inputs}

The purpose of this step is to identify informational inputs that will be required to resolve the decision statements and to determine which inputs require measurements.

This plan provides a risk assessment based on analytical data.

The inputs to the decisions include the following:

- Sample results from March 10, 2005, (indicating no contamination above remediation goals, but some levels above INL background [INEL 1996]) to provide some evidence that the release did not migrate along the drain line beyond the footprint of CPP-603

- $\quad$ COC list (see Table 2-1) 
- Sample results from soils under the south decontamination pad through the failed drain line elbow (data gap)

- Integrity test results for PLA-100115 outside of CPP-603 (data gap)

- Sample results from soils underlying PLA-100115 outside of CPP-603, if, in fact, integrity of the drain line was compromised (data gap).

There are data gaps for the soils underlying the origination of the drain pipe to PLA-100115 as well as integrity test results for the drain line outside of CPP-603 and subsequent sample results underlying the drain line if integrity was compromised. There is no record of the volume or concentration of the source, so the nature and extent of contamination is unknown. Given the nature of INTEC soils, any release under the drain pipe is assumed to travel more vertically than laterally.

\subsection{Study Boundaries}

The primary objectives of this step are to identify the population of interest, define the spatial and temporal boundaries that apply to the decision statement, define the scale of decision-making, and identify practical constraints that must be considered in the sampling design. Implementing this step helps ensure that the sampling design will result in the collection of data that accurately reflect the true condition of the site under investigation.

The study includes (1) soils directly under the floor drain and extending under the southeast corner of CPP-603, (2) the PLA-100115 drain line outside of CPP-603, and (3) the soils underlying the PLA-100115 drain line outside of CPP-603. The PLA-100115 drain line and underlying soils outside of CPP-603 are separated by the boundary of CERCLA Site CPP-01. These two areas, if necessary, will be remediated differently because soils within CPP-01 will be remediated as part of an existing CERCLA site. The connection of the floor drain to the PLA-100115 drain line under the south decontamination pad in CPP-603 is at approximately $6 \mathrm{ft}$ below grade. The connection with PLA-100116 is approximately $14 \mathrm{ft}$ below grade. The length of PLA-100115 is approximately $88 \mathrm{ft}$, with $28 \mathrm{ft}$ of length underlying CPP-603. The spatial boundary is the length of the PLA-100115 drain line, the soils directly beneath the floor drain, and the soils underlying the PLA-100115 drain line outside of CPP-603. The temporal boundary is the schedule on closure for the soils associated with PLA-100115 (see Section 7).

\subsection{Decision Rule}

The objective of this step is to define parameters of interest that characterize the population, specify the action level, and integrate previous data quality objectives outputs into a single statement that defines the conditions that would cause the decision-maker to choose among AAs. The decision rule typically takes the form of an "If/then" statement describing the action to take if one or more conditions are met.

The decision rules are specified in relation to RWMA/RCRA COC concentrations. For PSQ 1, the concentrations of the HWMA/RCRA COCs are of concern with regard to risk to human health,. For PSQ 2, the concentrations of HWMA/RCRA COCs are of concern only if the integrity of the line outside CPP-603 cannot be verified. The decision rules are as follows:

PSQ 1:

If the site specific risk assessment for HWMA/RCRA COC concentrations in the soil beneath the floor drain associated with the release from PLA-100115 indicates a risk to human health, 
then a NSIF will be submitted to the agencies for review and approval. Approval of the NSIF will be a criterion for certification of closure.

If a site specific risk assessment for HWMA/RCRA COC concentrations in the soil beneath the floor drain associated with the release from PLA-100115 do not pose a risk to human health, then no further action for the line under CPP-603 will be required under HWMA/RCRA closure, and no further investigation will be required.

PSQ 2:

If the site specific risk assessment for HWMA/RCRA COC concentrations in the soil beneath the drain line (if integrity is not verified and the line is removed) indicates a risk to human health, then the PLA-100115 drain line and associated soils may require further consideration and a NSIF will be submitted to the agencies for review and approval. Approval of the NSIF will be a criterion for certification of closure.

If the site specific risk assessment for HWMA/RCRA COC concentrations in the soil beneath the drain line (if integrity is not verified and the line is removed) indicates a risk to human health, then no further actions with regard to the PLA-100115 drain line and associated soils will be required under HWMA/RCRA closure.

\subsection{Decision Error Limits}

Because analytical data and test results can only estimate the true condition of the site under investigation, and, since data are intrinsically variable, decisions based on measurement data could potentially be in error. For this reason, the primary objective of this step is to determine which decision statements, if any, require a statistically based sample design.

A decision error occurs when the data lead the decision-makers to take an action when one is not necessary or to not take an action when one is warranted. For the purposes of this plan, the two decisions have the same two possible decision errors. The common decision is whether soil beneath the drain line (within CPP-603 or outside of CPP-603) was contaminated with COCs at concentrations that pose a risk to human health. The first error, a false-positive, is made if COC concentrations are determined to pose a risk to human health when, in fact, the concentrations are low enough to not pose a risk. The second error, a false-negative, is made if COC concentrations are determined not to pose a risk to human health when, in fact, there is a risk to human health from the soil COCs.

The soil data collected beneath the drainline will be used to calculate risk to human health based on the procedure in Appendix A. This procedure calls for a 95\% upper confidence limit (UCL) of HWMA/RCRA COC concentrations from the sample data. Threshold COC concentrations will not be back-calculated from the risk assessment, so error limits on the decisions are not specified. To minimize the decision errors, ample data will be collected to calculate a 95\% UCL whose half-width (UCL - mean) is no more than one standard deviation.

The 95\% UCL will be calculated assuming the data follow a normal distribution or can be transformed to approximate normality as:

$$
95 \% \text { UCL } \quad=\bar{x}+z_{0.95} \frac{s}{\sqrt{n}},
$$




$$
\begin{array}{ccc}
\bar{x} & = & \text { mean soil sample COC concentration } \\
z_{0.95} & = & 95^{\text {th }} \text { percentile of the standard normal distribution }=1.645 \\
s & = & \text { standard deviation of soil sample COC concentration } \\
n & = & \text { number of samples }
\end{array}
$$

Setting this 95\% UCL equal to 1 standard deviation results in $n=1.645^{2}=2.7$, which is then rounded up to 3 . Thus, three sample results will be used to assess risk to human health from HWMA/RCRA COCs.

\subsection{Design Optimization}

The objective of this step is to identify the best sampling and analysis design that satisfies the previous data quality objectives steps.

A review of the existing environmental data was performed and data gaps were identified. These data gaps include analysis of soils underlying the release location in PLA-100115 drain line under the floor drain, integrity test results for PLA-100115 drain line outside of CPP-603, and, if the drain line integrity has been compromised, sample results from soils underlying the drain line outside CPP-603.

Soil directly under the floor drain at the point where the drain line failed will provide the most conservative estimates of the nature of the release. At least three samples will be collected at depths below the drain line elbow. A gamma probe will be used to determine if contamination is increasing with depth or decreasing. If contamination levels increase with depth, further samples will be collected to support groundwater risk assessment conducted for the CERCLA NSIF. The initial three depths will be one within the first $4 \mathrm{ft}$ below the drain line elbow, one within 4 to $8 \mathrm{ft}$ below the drain line elbow, and one within 8 to $12 \mathrm{ft}$ below the drain line elbow.

The integrity test (described in Section 4) will provide information on whether the line can hold pressure or if the line could have released its contents to the environment. The integrity test will proceed in 1 or 2 phases, depending on the outcome of the first. Pressure will be tested for the pipe between CPP 603 and the connection to PLA-100116 first. If this test passes, the pressure test is complete. If the test fails, then pressure will be tested between CPP-603 and the preliminary boundary of CERCLA site CPP-01. No matter the outcome of the second test, the drain line will be removed within the CPP-01 boundary and three samples collected from under the pipe. If the second test fails, the drain line between CPP-603 and the CPP-01 boundary will also be removed and three samples collected from under the pipe.

For each segment requiring sampling, three samples will be collected from under the drain line, at regular intervals, for analysis. The location of the first sample will be randomly selected within the first third of the pipe starting from the eastern wall of CPP-603 and/or the western CPP-01 boundary. The other sample locations will follow on a regular interval. The random start will allow for inference to the population of soils underlying this section of drain line. 


\section{SAMPLING and INVESTIGATION APPROACH}

The following subsections provide guidance for integrity testing and soil characterization activities. The first section describes the investigative approach that will be performed to assess the integrity of the PLA-100115 drain line beyond the footprint of CPP-603. The integrity test will involve pressure testing of the line to determine if the pipe is intact. If the line does not hold pressure, soil sample will be collected from beneath the drain line. The second section describes the soil characterization activities to be performed beneath the drain under the south decontamination pad inside Building CPP-603 where releases are known to have occurred.

\subsection{Pipeline Integrity Test and Soil Sampling}

The integrity of PLA-100115 beyond the footprint of CPP-603 will be investigated by pressure testing using air. If the line is shown to be able to hold pressure, it will be concluded that no releases to the soils occurred ant the line and no further actions will be required for the line under the HWMA/RCRA closure. However, if the line fails to hold pressure, the soils above the line will be excavated, the line removed, and the soils beneath the line sampled for COCs.

\subsubsection{Pipeline Integrity Test Method}

The PLA-100115 line, that exists outside the footprint of CPP-603 will be pressure tested to determine integrity. ${ }^{\mathrm{d}}$ Excavations at points " $\mathrm{A}$ " (just outside the CPP-603 footprint) and " $\mathrm{C}$ " (at the intersection with line PLA-100116) will be performed allowing for the drain line to be cut and capped at either end (see Figure 4-1). The depth to the PLA-100115 line at point "A" is approximately 6-1/2 ft bgs and the depth to the line at Point "C" is approximately $14 \mathrm{ft} \mathrm{bgs.} \mathrm{Air-tight} \mathrm{caps/plugs} \mathrm{will} \mathrm{be} \mathrm{installed} \mathrm{at}$ both ends with means to attach a pressurized air line and pressure gauge. The line will be pressurized to 7 psi using air and monitored for 20 minutes for loss of pressure. If less than one psi is lost during the time interval (minimum 6 psi maintained for 20 minutes), the integrity of the PLA-100115 line between points " $A$ " and " $C$ " will be considered intact and no further action will be required to the line or associated soil under HWMA/RCRA closure.

If the line does not maintain pressure between points "A" and "C," soils samples will be collected from the excavation performed to remove the pipe between points " $\mathrm{B}$ " (boundary of the CERCLA soil site CPP-01) and "C" as described in Section 4.3. A second pressure test will then be performed between points " $A$ " and " $\mathrm{B}$ " following the same criteria as described above. If a pressure of 6 psi is maintained for 20 minutes, the integrity of the PLA-100115 line between points "A" and "B" will be considered intact and no further action will be required to the line or associated soil under HWMA/RCRA closure between these two points. If the line does not maintain pressure, soils samples will be collected from the excavation performed to remove the pipe between points " $A$ " and "B" as described in Section 4.3.

d. Integrity pressure test patterned after general tests performed by VCO closure projects at Reactor Technologies Complex. 


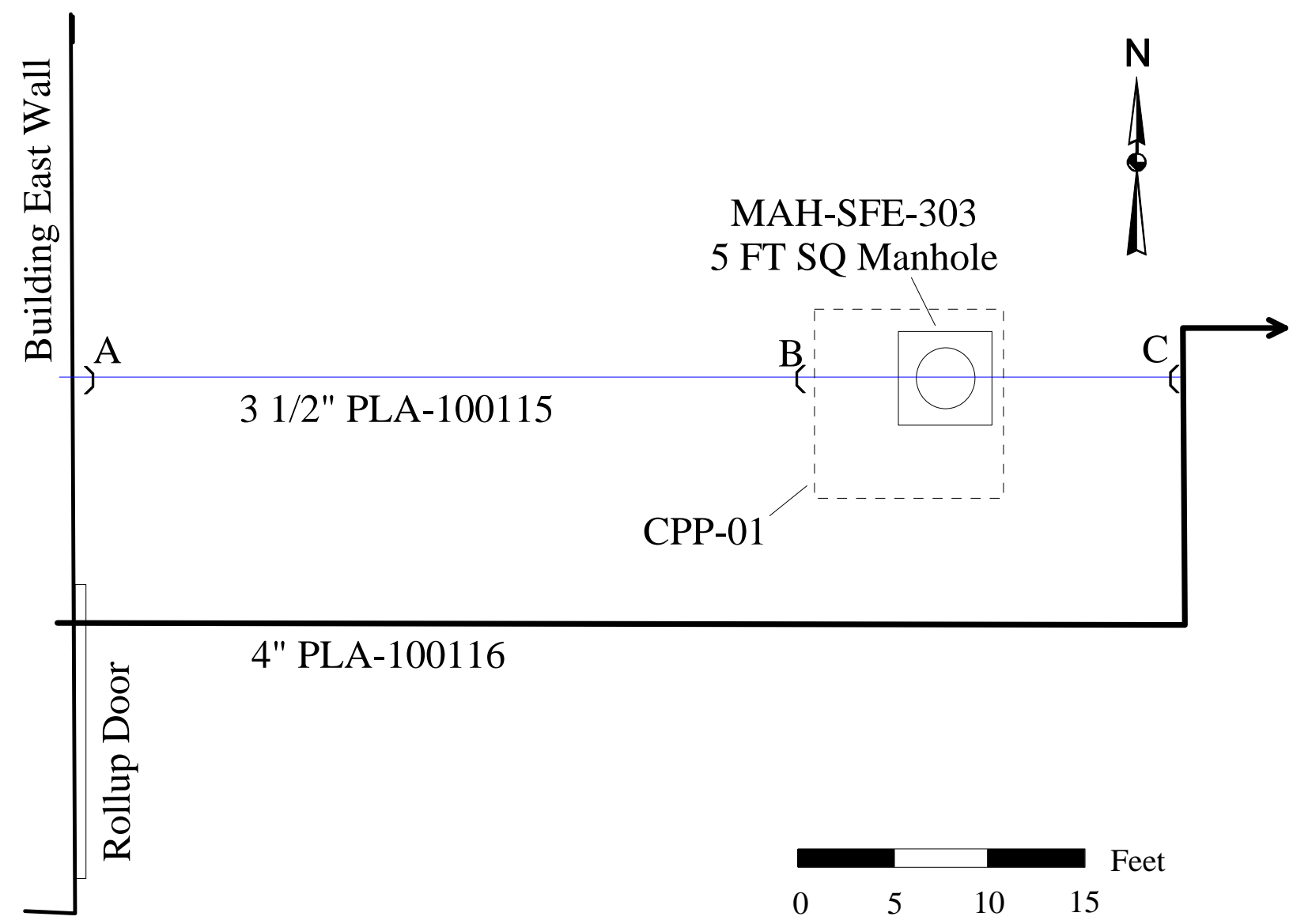

Figure 4-1. Isolation locations (A, B, C) for PLA-100115 drain line integrity pressure test.

\subsection{Characterization of Release Site}

Video images taken through the drain line under the decontamination pad indicate that a release to the environment has occurred at this point. To determine nature and vertical extent, three samples will be collected through the floor drain and into the underlying soils. Sample management will follow the guidelines described in Section 4.3.

\subsection{Sampling Methods}

Samples will be collected from beneath the south decontamination pad (see Figure 4-2) starting at the depth of the elbow area, approximately $6 \mathrm{ft}$ below the south decontamination pad floor. Sample interval will be from 0 to $4 \mathrm{ft}, 4$ to $8 \mathrm{ft}$, and 8 to $12 \mathrm{ft}$ as measured at the elbow area for a minimum of three sample sets. After the removal of the third sample set, a downhole gamma probe (gamma-ray logging tool) will be operated in move-stop-acquire mode to detect display gross gamma-radiation flux with depth. The suggested depth increment is 6 in. along the borehole. If radiation levels are decreasing or are non-detect in the 8 to $12 \mathrm{ft}$ interval, no further sampling will be required. However, if radiation levels increase between the second and third sample interval, an additional 4-ft soil core will be collected and processed for sample analysis. Sampling will continue until either radiation levels are shown to decrease or until the basalt interface is reached. Samples will be collected using a GeoProbe or equivalent percussion-hammer/direct-push rig. 


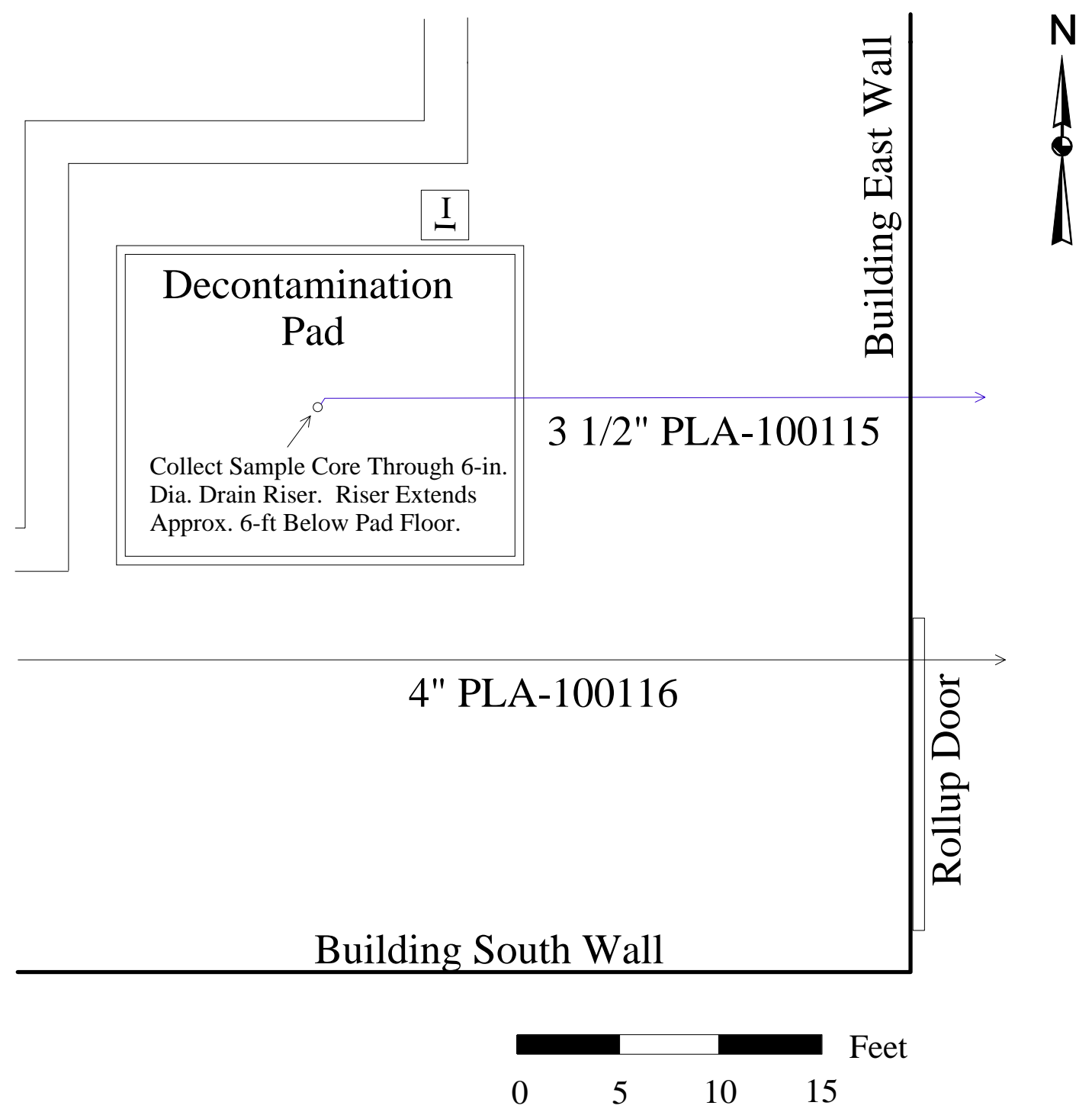

Figure 4-2. Sample location through the drain line at the decontamination pad inside CPP-603.

As necessary, samples will be collected from beneath the PLA-100115 drain line outside CPP-603 for pipe segments between points " $A$ " and " $B$ " and/or " $B$ " and "C" as determined by the integrity test performed (see Figure 4-1). A minimum of three grab samples will be collected from soils located 0 to 6 in. beneath the drain line for each segment that requires sampling. For each segment requiring sampling, three samples will be collected from under the drain line, at regular intervals, for analysis. The location of the first sample will be randomly selected within the first third of the pipe starting from the eastern wall of CPP-603 and/or the western CPP-01 boundary. The other sample locations will follow on a regular interval. The random start will allow for inference to the population of soils underlying this section of drain line.

In addition, QA/QC samples will be collected, as required, to satisfy the requirements of the QAPjP. Analysis results will be turned over to CERCLA to assist in waste disposition. 


\subsubsection{Soil Sampling Procedures}

4.3.1.1 Pre-sampling Meeting. Before sampling takes place, the sampling team will prepare for the sampling activity in accordance with applicable company procedures and participate in applicable pre-job briefings. The sampling team will discuss each project member's responsibilities, health and safety concerns during the sampling events, and sampling objectives and procedures. Sampling team members will be experienced in collecting the type of samples required for this project. They will also be trained in procedures for operation of the sampling devices to be employed. All sampling team members must be familiar with the specific objectives, sampling design, and sample collection requirements specified in the Field Sampling Plan and accompanying QAPjP (DOE-ID 2004).

4.3.1.2 Sample Containers and Preservation. The sample containers and preservation methods, as identified in the QAPjP, will be followed. Because certain COCs are volatile, care must be taken during the sampling process to minimize the loss of volatile analytes of interest. In accordance with the requirements specified in the QAPJP, all volatile organic samples will be collected first to minimize the loss of volatile organic analytes. In the event that sample volume recovery is limited, samples will be collected for analysis based on the priority list below:

1. VOCs

2. SVOCs

3. Metals

4. Radionuclides.

Idaho Cleanup Project Sample and Analysis Management will generate a sampling and analysis plan table and associated labels. The sample team leader or designee will ensure that any changes to this document regarding sampling frequency, location, and/or analysis are documented in the sample logbook according to applicable company procedures.

4.3.1.3 Sampling Equipment and Support Documentation. Sampling equipment, documentation, and any other supplies will be used and maintained in accordance with applicable company procedures. The following equipment and supplies are recommended for sampling at the task site:

- Characterization Plan (this document)

- Radiological work permit (as applicable)

- Laboratory contracts

- Logbook

- Chain-of-custody forms

- Personal protective equipment included in the job safety analysis and/or radiological work permit

- Wipes/absorbent towels

- $\quad$ Battery-operated (field) scale 
- Aluminum pans

- $\quad$ Plastic Ziploc bags

- En Core Sampler or equivalent

- Appropriate bottles/containers

- Sample labels

- Blue Ice

- $\quad$ Ice chests

- Adhesive tape (clear, duct, and strapping)

- $\quad$ Pens and markers

- Custody seals

- Parafilm

- Disposable spoons and scoops

- Decontamination solution.

4.3.1.4 Sampling Procedures. The goal of this sampling event is to obtain representative samples of soils from beneath the drain line and from below the PLA-100115 line. The preferred sample collection method is to use disposable sampling equipment in accordance with applicable company procedures. The precise methods and tools used to collect the samples will be documented in the project logbook.

A detailed description of the soil material will be recorded in the logbook. Sampling will be conducted as follows:

1. Conduct a pre-job briefing and review appropriate procedures prior to sampling.

2. Verify that the sampling activity has been scheduled with the facility and that all necessary personnel are available.

3. Establish appropriate radiological controls for the sampling location (e.g., tent or contamination area as appropriate per the radiological work permit) or verify that controls are established and currently in place.

4. Don the required personal protective equipment as specified in the health and safety plan, job safety analysis, and the radiological work permit.

5. Enter the area under direction of radiological control technician and/or field team leader.

6. Stage equipment. 
7. Under radiological control technician and/or industrial hygienist supervision, if required, and per instructions in the appropriate work control, drive or excavate to the depth where samples are to be collected.

8. Collect sample material.

9. Perform any required radiological and/or contamination surveys on the sample material to ensure the limits of the radiological work permit are not exceeded.

10. Collect the necessary sample aliquots. The 4-ft sample from the drain line will be emptied into a disposable aluminum pan where the contents will be thoroughly homogenized. Fill sample aliquot bottles. Note: VOC samples will be collected using guidance from SW-846 5035A. If soil characteristics or radiation fields associated with the soil prevent the appropriate use of SW-846 5035A, soil will be collected prior to mixing the sample medium and placed into a volatile-organic analysis sample container with minimal headspace. Any deviation from SW-846 5035A will be documented in the sampling logbook, as applicable.

11. Cap each sample container after it is filled, as appropriate.

12. If required, decontaminate the sample tools and any other used materials/tools between sample locations in accordance with applicable company procedures. As much as possible, disposable one-time-use materials will be employed. No free liquids are anticipated to be generated from the decontamination of sampling equipment.

13. Accumulate and package waste in accordance with Waste Generator Services' instructions.

14. Doff personal protective equipment and collect all dry disposable waste clothing/materials.

15. Remove samples from the area after the radiological control technician has surveyed and confirmed activity.

16. Contact Packaging and Transportation to coordinate shipment of radioactive samples.

17. Complete required shipping paperwork, and package and transport samples accordingly. Note: If alpha shipping screens are deemed necessary, this may impact hold time requirements for VOC analyses using Method 5035A, which requires the lab to preserve the samples within 48 hours of collection.

18. Manage waste as directed by Waste Generator Services.

A description will be made in the sample logbook of actual sampling activities and will include the following: sample numbers, time of sample collection (for each sample), how material was sampled, e.g., tools; physical consistency; any discrepancies from the description in this plan with regard to the actual phases present; presence of moisture; physical limitations; and if any sample set is not considered representative. Any deviations must be brought immediately to the field team leader's attention.

4.3.1.5 Sample Analysis. To ensure data of acceptable quality are obtained from the characterization project, standard EPA laboratory methods or technically appropriate methods for analytical determinations will be used to obtain sample data. Anticipated analytical methods to be used for this activity are identified in Table 4-2. 
Table 4-2. Analytical methods for constituents.

\begin{tabular}{|c|c|c|}
\hline \multicolumn{3}{|c|}{ Characterization Analytical Methods ${ }^{\mathrm{a}}$} \\
\hline Constituent & Analytical Method & $\begin{array}{l}\text { Solids Detection } \\
\text { Limits }\end{array}$ \\
\hline UTS metals & $\begin{array}{l}\text { EPA Methods 1311, 3010A, 7760A, } \\
\text { 6010B, and 7470A }\end{array}$ & $\begin{array}{l}0.2-1,000 \mathrm{mg} / \mathrm{kg} \\
\text { depending on metal }\end{array}$ \\
\hline CLP TAL metals & $\begin{array}{l}\text { EPA Methods 3010A, 7760A, 6010B, } \\
\text { and 7470A }\end{array}$ & $\begin{array}{l}0.2-1,000 \mathrm{mg} / \mathrm{kg} \\
\text { depending on metal }\end{array}$ \\
\hline Appendix IX TAL VOCs & EPA Method $8260 B^{b}$ & $\begin{array}{l}\text { 5-100 ug/kg depending } \\
\text { on VOC }\end{array}$ \\
\hline Appendix IX TAL SVOCs & EPA Method 8270C & $\begin{array}{l}660-3,300 \mathrm{ug} / \mathrm{kg} \\
\text { depending on SVOC }\end{array}$ \\
\hline PCBs & EPA Method 8082 & $350 \mathrm{ug} / \mathrm{kg}$ \\
\hline $\mathrm{H}-3$ & LSC & $20 \mathrm{pCi} / \mathrm{g}$ \\
\hline Sr-90 & GFP & $0.5 \mathrm{pCi} / \mathrm{g}$ \\
\hline Tc-99 & LSC or GFP & $1 \mathrm{pCi} / \mathrm{g}$ \\
\hline $\mathrm{I}-129$ & LEPS or GFP & $1 \mathrm{pCi} / \mathrm{g}$ \\
\hline Np-237 & ALS & $0.05 \mathrm{pCi} / \mathrm{g}$ \\
\hline U-234, -235, and -238 & ALS & $0.05 \mathrm{pCi} / \mathrm{g}$ \\
\hline Pu isotopes & ALS & $0.05 \mathrm{pCi} / \mathrm{g}$ \\
\hline Pu-242 & ALS & $0.05 \mathrm{pCi} / \mathrm{g}$ \\
\hline Pu-241 & LSC & $1 \mathrm{pCi} / \mathrm{g}$ \\
\hline Am-241 and -243 & ALS & $0.05 \mathrm{pCi} / \mathrm{g}$ \\
\hline Gamma emitters & GMS & $\sim 0.1 \mathrm{pCi} / \mathrm{g}$ \\
\hline \multicolumn{3}{|c|}{$\begin{array}{l}\text { ALS = alpha spectrometry. } \\
\text { CLP = Contract Laboratory Program. } \\
\text { GFP = gas flow proportional. } \\
\text { GMS = gamma spectrometry. } \\
\text { LEPS = low energy photon spectrometry. } \\
\text { LSC = liquid scintillation counting. } \\
\text { PCB = polychlorinated biphenyl. } \\
\text { TAL = target analyte list. } \\
\text { UTS = Universal Treatment Standard. }\end{array}$} \\
\hline \multicolumn{3}{|c|}{$\begin{array}{l}\text { b. Samples will be collected using guidance from SW-846 5035A, as applicable. (The determinative method for } \\
\text { volatile organic analysis will be SW-846 8260B.) }\end{array}$} \\
\hline
\end{tabular}

Any deviations from this information will be fully documented. If the laboratory determines a need to deviate from these requirements, the laboratory will inform the project manager and obtain his approval prior to deviating from the requirements. 


\subsection{Quality Assurance Objectives}

The QAPjP (DOE-ID 2004) pertains to QA and QC for all environmental, geotechnical, geophysical, and radiological testing, analysis, and data review. Specific requirements to support the work, including QA/QC requirements for all sample and analyte types that may potentially be collected, are discussed below.

\subsubsection{Project Quality Objectives}

Quality assurance objectives for this project will be met through a combination of field and laboratory checks. Field checks will consist of collecting field duplicates and blanks, as appropriate. Laboratory checks consist of initial and continuing calibration samples, laboratory control samples, matrix spikes, and matrix spike duplicates. Laboratory QA is detailed in the QAPjP (DOE-ID 2004).

\subsubsection{Precision and Accuracy}

Precision and accuracy goals are established for organic, inorganic, and radioanalytical analyses in the QAPjP (DOE-ID 2004).

\subsubsection{Completeness}

Overall completeness of the data collection effort is assessed by comparing the number of samples collected and analyzed to the number of samples planned (DOE-ID 2004). Field completeness compares the number of samples collected to the number of samples received at the analytical laboratory, while analytical completeness compares the number of samples received to the number of analyses performed. Field sampling completeness is affected by factors such as equipment and instrument malfunctions and insufficient sample recovery. Analytical completeness is affected if (a) samples are not analyzed within the defined holding time, (b) a sample is damaged during handling or storage, or (c) the laboratory data cannot be validated and the sample cannot be reanalyzed.

Critical samples are defined as those required to achieve project objectives or to set limits on decision errors (e.g., samples to assess compliance with a cleanup level); while non-critical samples are those required for secondary or supporting information (e.g., provide indications of trends over time).

Critical sample collection will be completed to the extent technically and administratively feasible and within the project schedule. If a sample cannot be collected at the specified location due to infrastructure constraints, then an alternate location will be identified. As applicable, an alternate location will be identified and cleared with INTEC facility personnel prior to mobilization.

The completeness goal for sample collection and gamma screening is 80 percent.

\subsubsection{Representativeness}

Representativeness is evaluated by assessing the accuracy and precision of the sampling program and expressing the degree to which samples represent actual site conditions. Confirming that sampling locations are properly selected and a sufficient number of samples are collected to meet the objectives of the investigation best satisfies the representativeness criterion. For this characterization effort, three sample locations at each suspected release site will provide adequate information to determine the nature of the suspected release. 


\subsubsection{Comparability}

Comparability is a qualitative measure of the confidence with which one data set can be compared to another. These data sets include data generated by different laboratories performing the work, data generated by laboratories in previous studies, data generated by the same laboratory over a period of several years, or data obtained using different sampling techniques or analytical protocols. Data comparability will be achieved using standard methods of sample collection and handling.

\subsubsection{Data Validation and Reduction}

The laboratory-generated data will be validated to Level A. Reduction of field data will include cross-referencing the sampling and analysis plan table with sample labels, logbooks, and chain-of-custody forms. Prior to sample shipment to the laboratory, field personnel will ensure that all information is properly documented.

\subsubsection{Quality Assurance Objectives for Measurement}

The QA objectives are specifications that the monitoring and sampling measurements identified in the QAPjP must meet to produce acceptable data for the project. The technical and statistical quality of these measurements must be properly documented. Precision, accuracy, method detection limits, and completeness must be specified for hydraulic and chemical measurements. Specific QA objectives are given in the QAPjP (DOE-ID 2004). 


\section{WASTE MANAGEMENT}

The waste anticipated from this sampling event may include the following items:

- Contaminated personal protective equipment, wipes, bags, and other paper and plastic trash

- Contaminated sampling equipment

- Unused, unaltered, and altered sample material

- Used sample containers and disposable sampling equipment

- Soil cuttings and concrete not returned to the bore hole

- Tents and/or other radiological control items.

Waste generated during this characterization effort will be managed per the applicable hazardous waste determination and the WAG 3 CERCLA notice of soil disturbance. Waste Generator Services will generate hazardous waste determinations for determining the disposition routes for waste generated during sampling and analysis. 


$$
\text { 5-2 }
$$




\section{DOCUMENT MANAGEMENT AND SAMPLE CONTROL}

The following sections summarize document management and sample control, describe sample handling, and discuss chain of custody, radioactivity screening, and sample packaging for shipment to the analytical laboratories.

\subsection{Documentation}

The field team leader will be responsible for controlling and maintaining all field documents and records and for verifying that all required documents are submitted to the ICP Administrative Records and Document Control and to the independent Professional Engineer certifying closure.

\subsubsection{Sample Container Labels}

Labels will be completed and placed on the containers before sample collection. Information necessary for label completion include sample date, time, and the sampler's initials.

\subsubsection{Field Guidance Form}

Field guidance forms provided for each sample location will be generated from the sampling and analysis plan database. These forms contain the following information:

- Analysis type

- Container size and type

- Sample preservation

- Other laboratory-specific information.

\subsubsection{Field Logbook}

Field logbooks will be used to record information necessary to interpret the analytical data in accordance with Administrative Records and Document Control format and will be managed according to internal ICP procedures.

6.1.3.1 Sample Logbook. The field teams will use a sample logbook. The sample logbook will contain, at a minimum, the following information:

- Physical measurements

- QC samples

- Sample information (sample location, analyses requested for each sample, sample matrix, gamma survey results)

- Shipping information (collection dates, shipping dates, cooler identification number, destination, chain-of-custody number, name of shipper) 
- Daily area activities

- Daily weather observations.

\subsection{Sample Handling}

Analytical samples for laboratory analyses will be collected in pre-cleaned, laboratory-certified containers and packaged according to the American Society for Testing and Materials or EPA-recommended procedures. The QA samples will be included to satisfy the QA/QC requirements for the field operation as outlined in the QAPjP (DOE-ID 2004). Qualified (Sample and Analysis Management-approved) analytical and testing laboratories will analyze the samples.

\subsubsection{Sample Preservation}

Soil samples will be preserved immediately upon sample collection in accordance with the requirements in the QAPjP (DOE-ID 2004). Soil and rinsate samples and samples requiring cooling to $4^{\circ} \mathrm{C}$ will be placed in coolers containing frozen, reusable ice immediately after sample collection and survey by radiological control.

\subsubsection{Chain-of-Custody Procedures}

The chain-of-custody procedures will be followed in accordance with the QAPjP and internal ICP procedures. Filled sample containers will be stored in a secured area accessible only to the field team members.

\subsubsection{Transportation of Samples}

Samples will be prepared for shipment, along with completed applicable shipping papers. Samples will be packaged and provided to ICP Packaging and Transportation for transport in accordance with applicable company procedures.

6.2.3.1 Custody Seals. Custody seals will be placed on all shipping containers in such a way as to ensure that sample integrity is not compromised by tampering or unauthorized opening. The seals will be signed by a member of the field team. Clear, plastic tape will be placed over the seals and the signature to ensure that the seals are not damaged during shipment. 


\section{SCHEDULE}

The process for development of the schedule to implement the characterization plan for PLA-100115 is identified in the HWMA/RCRA Less Than 90-day Generator Closure Report for the VES-SFE-126. This states the following:

Implement Characterization Plan: The soil characterization plan will be implemented after the basin hazards, water and sludge, have been removed. The implementation and completion dates will be negotiated with the DEQ.

In light of this, upon elimination of the basin hazards, a schedule for implementation and completion of soil characterization will be provided to the DEQ. In addition, implementation of this plan must be coordinated with planned excavations for the VES-SFE-20 tank vault removal, the VES-SFE-106 tank and vault removal, and the excavation of CERCLA soil site CPP-01. Upon DEQ's approval of this schedule, the activities will proceed. 


\section{REFERENCES}

40 CFR 262.34, 2005, “Accumulation time,” Code of Federal Regulations, Office of the Federal Register, September 2005.

DOE-ID, 1999, Final Record of Decision, Idaho Nuclear Technology and Engineering Center, Operable Unit 3-13, Idaho National Engineering and Environmental Laboratory, Idaho Falls, Idaho, DOE/ID-10660, Rev. 0, U.S. Department of Energy Idaho Operations Office, October 1999.

DOE-ID, 2004, Quality Assurance Project Plan for Waste Area Groups 1, 2, 3, 4, 5, 6, 7, 10, and Deactivation, Decontamination, and Decommissioning, DOE/ID-10587, Rev. 8, U.S. Department of Energy Idaho Operations Office, March 2004.

DOE-ID, 2006, Operable Unit 3-13, Group 3, Other Surface Soils Remediation Sets 4-6 (Phase II) Remedial Design/Remedial Action Work Plan (Draft), DOE/ID-11254, Rev. 0, Department of Energy Idaho Operations Office, April 2006.

DOE-NE-ID, 2005a, Action Memorandum for the Non-Time Critical Removal Action at the CPP-603A Basins, Idaho Nuclear Technology and Engineering Center, DOE/NE-ID-11194, Rev. 0, U.S. Department of Energy Idaho Operations Office, January 2005.

DOE-ID, 2005b, Field Sampling Plan for Investigative Characterization of Soil Around Line PLA-100115 Outside CPP-603, DOE/NE-ID-11219, Rev. 0, U.S. Department of Energy Idaho Operations Office, March 2005.

EPA, 2000a, Data Quality Objective Process for Hazardous Waste Site Investigations, EPA QA/G-4HW, U.S. Environmental Protection Agency, January 2000.

EPA, 2000b, Guidance for Data Quality Assessment: Practical Methods for Data Analysis, U.S. Environmental Protection Agency.

ICP, 2005, Characterization Summary Report for Operable Unit 3-13, Group 7, VES-SFE-20 Hot Waste System at INTEC, ICP/EXT-05-00993, Rev. 0, Idaho National Laboratory, Idaho Cleanup Project, September 2005.

INEEL, 2000, HWMA/RCRA Less Than 90-day Generator Closure Report for the VES-SFE-126, INEEL/EXT-2000-00582, Idaho National Engineering and Environmental Laboratory, May 2000.

INEL, 1996, Executive Summary for Background Dose Equivalent Rates and Surficial Soil Metal and Radionuclide Concentrations for the Idaho National Engineering Laboratory, INEL-94/0250 (Exec Sum), Rev. 1, Idaho National Engineering Laboratory, September 1996.

SW-846, Method 5035A, 2002, "Closed-System Purge-and-Trap and Extraction for Volatile Organics in Soil and Waste Samples,” Rev. 1, Draft, Environmental Protection Agency, July 2002.

SW-846, Method 8260B, 1996, "Volatile Organic Compounds by Gas Chromatography/Mass Spectrometry (GC/MS),” Rev. 2, Environmental Protection Agency, December 1996.

Verwolf, M. C., DOE Idaho, to Koch, D. F., DEQ, and Ceto, N., April 28, 2005, “Transmittal of the Limitations and Validation (L\&V) Reports for Investigative Characterization of Soil Around Line PLA-100115,” CCN 300174. 


\section{DRAWINGS}

The following drawings were used to develop the information in this characterization plan. They are not included in this report per DOE O 471.3, "Identifying and Protecting Official Use Only Information.”

106772, INEEL Reference Drawing, ANP Assembly \& Maintenance Bldg. 607 First Floor \& Pool Foundation Plans-Hot Shop, Idaho National Engineering and Environmental Laboratory, 902-3-ANP-607-S128, Rev. B, May 1961.

054091, INL Reference Drawing, CPP-603, Decontamination Pad Shower Curtain-Assembly and Details, Idaho National Laboratory, Rev. 2, June 1982.

054835, INL Reference Drawing, Drain, Floor, Idaho National Laboratory, Rev. A, May 1969.

054834, INL Reference Drawing, Bucket - Floor Drain, Idaho National Laboratory, Rev. A, May 1969.

054833, INL Reference Drawing, Liner Installation Decontamination Pad, Idaho National Laboratory, May 1969, Rev. A.

CPP6031, INL Reference Drawing, CPP-603 Wet \& Dry fuel Storage Building First Floor Plan, Idaho National Laboratory, March 2006, Rev. NA.

340570, INL Reference Drawing, CPP-603 Space Occupancy Floor Plan, Idaho National Laboratory, February 1996, March 2006, Rev. 6.

105946, INL Reference Drawing, Fuel Element Cutting Facility Underground Piping Plan, Idaho National Laboratory, 834-CPP-603-P1, Rev. 15, July 1995.

055345, INL Reference Drawing, CPP - Area Underground Utilities Systems, Rev. 16, November 1997.

105959, INL Reference Drawing, Fuel Element Cutting Facility Floor Slab Plan \& Details, Rev. 5, September 1992.

105958, INL Reference Drawing, Fuel Element Cutting Facility Floor Slab Details \& Car Puller Foundation, Idaho National Laboratory, 834-CPP-603-S5, Rev. 15, May 1969.

624443, INL Reference Drawing, INEEL OU 3-13 Group 7 VES-SFE-20 Hot Waste Tank Remedial Design Phase II Piping Plot Plan - Demolition, Rev. , June 2003. 
9-2 


\section{Appendix A}

\section{HWMA/RCRA Closure Risk Assessment Methodology for}

\section{Environmental Media}


A-2 


\section{Appendix A}

\section{HWMA/RCRA Closure Risk Assessment Methodology for Environmental Media}

This appendix presents the methodology that will be used to evaluate the risks associated with a release of HWMA/RCRA constituents for the purpose of closure of the less than 90-day generator closure for the VES-SFE-20 tank system located at INTEC, INL Site. To support this closure, Section A-1 provides the regulatory basis for evaluating the risk associated with the HWMA/RCRA constituents to demonstrate compliance with the closure performance standards for media associated with tank systems (IDAPA 58.01.05.009 [40 CFR 265.111 and 265.197(a)]. The remaining sections present the methodology to evaluate the contamination levels found in the soil associated with a release to determine if additional actions are necessary to protect human health and the environment. This evaluation will use a two-tier process to evaluate the risks. First, the sample results of the HWMA/RCRA constituents will be compared against the EPA Region IX preliminary remediation goals (PRGs) (Section A-2). This is a screening to help identify areas, contaminants, and conditions that do not require further attention at a particular site. If this comparison identifies that additional evaluation of one or more contaminants is necessary, then the second step will proceed (Section A-3), performing a site-specific risk assessment in accordance with EPA guidance (EPA 1989, 2001a).

\section{A-1. REGULATORY BASIS}

Since 1987, EPA guidance has interpreted the regulations governing closure of hazardous waste management units as requiring complete removal of all hazardous wastes and liners, and removal or decontamination of leachate, soils, and other materials contaminated with hazardous waste or hazardous constituents to the extent necessary to protect human health and the environment (52 FR 8704, 1987). The EPA further clarified that this interpretation means that, except for hazardous waste and liners, the regulations do not require complete removal of all contamination (e.g., removal to background levels) from a unit being closed to achieve clean closure. Rather, some limited quantity of hazardous constituents might remain in environmental media after clean closure provided that their concentrations are below levels that may pose a risk to human health and the environment. The EPA also took the position that the amount of hazardous constituents that might remain in environmental media after clean closure should be identified through appropriate application of risk information using available constituent-specific limits or factors that have undergone agency review (e.g., maximum contaminant levels or health-based limits calculated using a verified reference dose [RfD]), using toxicity information submitted by a facility owner/operator and approved by the EPA when such limits or factors were not available, or using background comparisons.

The EPA has provided additional guidance on identifying the amount of hazardous constituents that might remain in environmental media after clean closure. The EPA's position is that the procedures and guidance generally used to develop protective, risk-based, media cleanup standards for the RCRA corrective action and CERCLA cleanup programs are also appropriate to define the amount of hazardous constituents that may remain in environmental media after clean closure. In other words, site-specific, risk-based media cleanup levels developed under the RCRA corrective action and CERCLA cleanup programs are appropriate levels at which to define clean closure (55 FR 8666, 1990; 55 FR 30798, 1990; 61 FR 19432, 1996; Cotsworth 1998). In addition, EPA has interpreted current closure regulations to allow appropriate use of nonresidential exposure assumptions when identifying the amount of decontamination necessary to satisfy the "remove or decontaminate" standard (Cotsworth 1998). 


\section{A-2. Screening Risk Threshold}

The initial screening to assess contaminants in soil will use the EPA Region IX PRGs. Preliminary remediation goals are chemical concentrations that correspond to fixed levels of risk (i.e., either a one-in-one million $\left[10^{-6}\right]$ cancer risk or a noncarcinogenic hazard quotient of 1 ) in soil, air, and water. These risk-based concentrations have been derived from standardized equations combining exposure information assumptions with EPA toxicity data. They are considered by EPA to be protective for humans (including sensitive groups) over a lifetime.

To facilitate the assessment of the risk associated with a release from the SFE-126 tank system, Table A-1 has been developed. This table identifies the HWMA/RCRA contaminants of concern and the associated Region IX PRG levels, using a residential scenario. It is noted that use of a residential scenario is a conservative scenario for this screening step. In addition, chemical concentrations above these PRG screening levels would not automatically designate a site as "dirty" or trigger a response action. However, exceeding a PRG suggests that further evaluation of the potential risks that may be posed by site contaminants is appropriate. In this situation, the site-specific risk threshold evaluation would be initiated, as identified in Section A-3.

As necessary, the screening evaluation will compare the sample results to natural background levels. This comparison is necessary since, in some cases, the natural background concentrations associated with the chemical constituents are higher than the risk-based PRG concentrations. An example of this situation is the levels of arsenic that are natural in soils at the INL Site. The screening evaluation will also use the most current information for EPA's Region IX PRGs since they are updated by EPA when new information is available.

In summary, for purposes of closure of the VES-SFE-126 tank system, the risk presented by the environmental media of concern will be considered acceptable if the total excess cancer risk does not exceed 1E-06 and the hazard index is less than one. As a first step, the contaminants in the soil will be compared to the Region IX risk-based screening levels to identify whether further evaluation is required.

Table A-1. Screening levels for potential HWMA/RCRA constituents in releases associated with PLA-100115.

\begin{tabular}{|c|c|c|}
\hline CAS No. & HWMA/RCRA Analyte ${ }^{\mathrm{a}}$ & $\begin{array}{c}\text { Region IX PRG Concentration } \\
\text { (Residential Use) } \\
\text { (mg/kg) }\end{array}$ \\
\hline 67-64-1 & Acetone & $1.4 \mathrm{E}+04$ \\
\hline $7429-90-5$ & Aluminum & $7.6 \mathrm{E}+04$ \\
\hline $7440-38-2$ & Arsenic & 3.9E-01 \\
\hline $7440-39-3$ & Barium and compounds & $5.4 \mathrm{E}+03$ \\
\hline $117-81-7$ & Bis(2-ethylhexyl)phthalate (DEHP) & $3.5 \mathrm{E}+01$ \\
\hline $85-68-7$ & Butyl benzyl phthalate & $1.2 \mathrm{E}+04$ \\
\hline $7440-43-9$ & Cadmium and compounds & $3.7 \mathrm{E}+01$ \\
\hline $75-15-0$ & Carbon disulfide & $3.6 \mathrm{E}+02$ \\
\hline $108-90-7$ & Chlorobenzene & $1.5 \mathrm{E}+02$ \\
\hline
\end{tabular}


Table A-1. (continued).

\begin{tabular}{|c|c|c|}
\hline CAS No. & HWMA/RCRA Analyte $^{\mathrm{a}}$ & $\begin{array}{c}\text { Region IX PRG Concentration } \\
\text { (Residential Use) } \\
\text { (mg/kg) }\end{array}$ \\
\hline $75-45-6$ & Chlorodifluoromethane & $3.4 \mathrm{E}+02$ \\
\hline $75-00-3$ & Chloroethane & $3.0 \mathrm{E}+00$ \\
\hline \multirow[t]{2}{*}{$74-87-3$} & Chloromethane (methyl chloride) & $4.7 \mathrm{E}+01$ \\
\hline & Total Chromium (1:6 ratio Cr VI:Cr III) & $2.1 \mathrm{E}+02$ \\
\hline $7440-48-4$ & Cobalt & $9.0 \mathrm{E}+02$ \\
\hline $7440-50-8$ & Copper and compounds & $3.1 \mathrm{E}+03$ \\
\hline $75-34-3$ & 1,1-Dichloroethane & $5.1 \mathrm{E}+02$ \\
\hline $75-35-4$ & 1,1-Dichloroethylene & $1.2 \mathrm{E}+02$ \\
\hline $100-41-4$ & Ethylbenzene & $4.0 \mathrm{E}+02$ \\
\hline 7439-92-1 & Lead & $4.0 \mathrm{E}+02$ \\
\hline 7487-94-7 & Mercury and compounds & $2.3 \mathrm{E}+01$ \\
\hline \multirow[t]{2}{*}{$7440-02-0$} & Nickel (soluble salts) & $1.6 \mathrm{E}+03$ \\
\hline & $\begin{array}{l}\text { PCBs (unspeciated mixture, high risk, } \\
\text { e.g., Aroclor 1254) }\end{array}$ & $2.2 \mathrm{E}-01$ \\
\hline $7782-49-2$ & Selenium & $3.9 \mathrm{E}+02$ \\
\hline $7440-22-4$ & Silver and compounds & $3.9 \mathrm{E}+02$ \\
\hline $630-20-6$ & 1,1,1,2-Tetrachloroethane & $3.2 \mathrm{E}+00$ \\
\hline $127-18-4$ & $\begin{array}{l}\text { Tetrachloroethylene } \\
\text { (PCE)(tetrachloroethene) }\end{array}$ & 4.8E-01 \\
\hline $7440-28-0$ & Thallium and compounds & $5.2 \mathrm{E}+00$ \\
\hline $71-55-6$ & 1,1,1-Trichloroethane & $1.2 \mathrm{E}+03$ \\
\hline $79-00-5$ & 1,1,2-Trichloroethane & 7.3E-01 \\
\hline $79-01-6$ & Trichloroethylene (TCE) (trichloroethene) & $5.3 \mathrm{E}-02$ \\
\hline $108-88-3$ & Toluene & $5.2 \mathrm{E}+02$ \\
\hline $7440-62-2$ & Vanadium and compounds & $7.8 \mathrm{E}+01$ \\
\hline 75-01-4 & Vinyl chloride (child/adult) & 7.9E-02 \\
\hline $1330-20-7$ & Xylenes & $2.7 \mathrm{E}+02$ \\
\hline $7440-66-6$ & Zinc & $2.3 \mathrm{E}+04$ \\
\hline $\begin{array}{l}\text { a. Theses analytes a } \\
\text { Report for the VES- } \\
\text { VES-SFE-20 Hot W }\end{array}$ & $\begin{array}{l}\text { IWMA/RCRA COCs identified in the } H W M A / R C R A \\
6 \text { (INEEL 2000) and the Characterization Summary } \\
\text { stem at INTEC (ICP 2005). }\end{array}$ & $\begin{array}{l}\text { than 90-day Generator Closure } \\
\text { t for Operable Unit 3-13, Group 7, }\end{array}$ \\
\hline
\end{tabular}




\section{A-3. SITE SPECIFIC RISK/EXPOSURE ASSESSMENT}

If the evaluation of the Region IX PRGs identify an exceedance requiring further evaluation, then an exposure assessment will be completed to estimate the type, duration, and magnitude of exposure that receptors may experience because of contact with the COCs. A conceptual site model, which illustrates the contaminant sources, primary release mechanisms, secondary sources and release mechanisms, exposure pathways, exposure routes, and receptors that will be evaluated by the site-specific risk assessment is presented in Figure A-1. The conceptual site model graphically presents the potentially complete exposure routes. Each potentially complete exposure route will be evaluated in detail during the risk assessment using available site-specific parameters and characterization data.

The exposure assessment has both qualitative and quantitative components. The qualitative component consists primarily of evaluating potentially exposed receptor populations and potential exposure pathways. The quantitative evaluation consists of estimating the exposure point concentrations within the environmental media and quantifying the intake factor associated within each pathway. The qualitative evaluation is presented in the conceptual site model (see Figure A-1) and the quantitative evaluation will be completed using sampling data.

\section{A-3.1 Identification of Potentially Exposed Receptor Populations}

As shown in Figure A-1, the only potentially exposed receptor population that will be evaluated is an occupational receptor. The INEEL Comprehensive Land Use Plan (INEEL 2005) describes the land use of the INL Site, which is currently government-controlled industrial use. The term "controlled" means that unrestricted public access to the INL Site is not available. Access to INL Site facilities requires proper clearance, training, or escort and controls for security reasons and to limit the potential for unacceptable exposures. A security force is used to limit access to approved personnel and visitors. These controls are estimated to be in place until at least 2095. Because the current land use includes continued utilization of operating facilities and access to these facilities is controlled, the only potential receptor is an occupational worker during the current land use scenario.

Future land use scenarios are identified in the Long-Term Land Use Future Scenarios for the Idaho National Engineering Laboratory (DOE-ID 1995). This document was developed using a stakeholder process that involved a public participation forum, a public comment period, and the INL Citizens Advisory Board. Following review and comment by the public participation forum the document underwent a 30-day public comment period and was subsequently submitted to the Board for review and recommendations. No recommendations for residential use of any portion of the INL Site until at least 2095 have been received to date. 


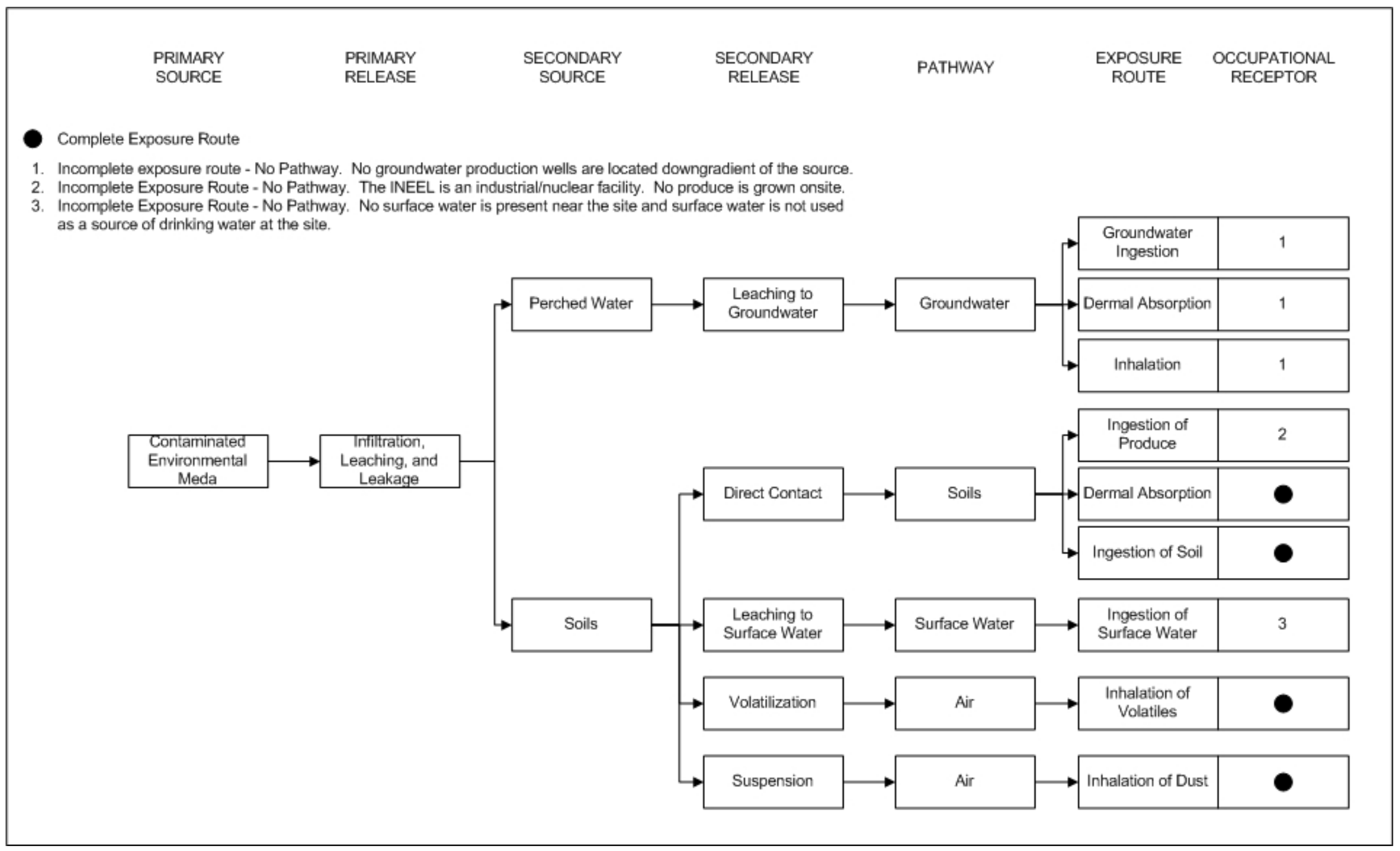

Figure A-1. HWMA/RCRA closure risk assessment conceptual site model. 
The INL Site is an industrial nuclear facility that is located in a very rural area with a low population density and projected low growth. Future residential use, especially those areas that are currently or have historically been used by INL Site operations, is extremely unlikely. Therefore, for purposes of the site-specific risk assessment, no residential receptors populations will be evaluated.

\section{A-3.2 Identification of Potential Exposure Pathways}

The conceptual site model includes various exposure pathways that were determined to be potentially complete and were selected for further evaluation based on the nature of the contamination that may be left in place following HWMA/RCRA closure activities. These pathways are summarized in Table A-2. It should be noted potentially complete exposure pathways are expected to vary between different closure sites due to the variation of site-specific contaminants or the presence of engineering features that prevent exposure from occurring. Each potentially complete exposure pathway will be evaluated and the results documented in the site-specific risk assessment.

Table A-2. Potentially complete exposure pathways to be quantitatively evaluated.

\begin{tabular}{|c|c|c|}
\hline $\begin{array}{c}\text { Potentially Exposed } \\
\text { Population }\end{array}$ & Scenario & Potentially Complete Exposure Pathways \\
\hline \multirow{4}{*}{$\begin{array}{l}\text { Occupational } \\
\text { worker }\end{array}$} & \multirow[t]{4}{*}{ Current and future land use } & Inhalation of volatile organic compounds \\
\hline & & Inhalation of airborne particulates \\
\hline & & Ingestion of surface soil \\
\hline & & Dermal absorption. \\
\hline Residential & Current land use & $\begin{array}{l}\text { Current use of the INL Site is for government- } \\
\text { controlled industrial activities (unrestricted } \\
\text { public access to the INL Site is not available); } \\
\text { there are no potentially complete residential } \\
\text { exposure scenarios. }\end{array}$ \\
\hline Residential & Future land use & $\begin{array}{l}\text { Future land use scenarios are identified in the } \\
\text { Long-Term Land Use Future Scenarios for the } \\
\text { Idaho National Engineering Laboratory } \\
\text { (DOE-ID 1995). The document identifies } \\
\text { anticipated activities through } 2095 \text { and projects } \\
\text { that the current industrial uses will continue at } \\
\text { the INL Site through at least 2095. Therefore, a } \\
\text { future residential exposure scenario is unlikely } \\
\text { and is not a complete exposure pathway. }\end{array}$ \\
\hline
\end{tabular}




\section{A-3.3 Derivation of Exposure-Point Concentrations}

Validated analytical data from post-closure sampling and analysis activities will be used to estimate exposure point concentrations for each COC. COCs were established, based on process knowledge and historical analytical data from sampling of the tank system being closed or related processes. The risk assessment will account for all contaminants detected, regardless of their inclusion as COCs in the closure plan, during post-closure characterization of the tank system, except as outlined below:

- Data that are rejected per the method validation will be eliminated from the data set used to determine the exposure point concentrations.

- Contaminants that are not detected in any samples will be screened from further consideration.

- Contaminants for which there are both true detects and nondetects will be retained for evaluation and nondetect data will be assigned an appropriate concentration during data quality assessment using EPA recommended strategies, as presented in Guidance for Data Quality Assessment: Practical Methods for Data Analysis (EPA 2000).

- Contaminants for which there is no EPA approved toxicity information (e.g., EPA's Integrated Risk Information System [IRIS] [EPA 2003a] or Region 9 Preliminary Remediation Goal Table [EPA 2003b]) will be screened from further consideration.

Additional screening methodologies may be used in accordance with EPA guidance as necessary and appropriate and will be documented in the site-specific risk assessment.

The screening process is designed to be conservative such that all contaminants that have a reasonable potential for causing adverse human health effects pass the screening and, therefore, will be evaluated in the site-specific risk assessment. Because of the uncertainty associated with any estimate of exposure concentration, the 95\% upper confidence level (UCL) is the most appropriate estimate for the COC concentrations (EPA 2001a). Specific calculations for the 95\% UCL are dependent upon data distribution (i.e., are the data distributed normally or log normally). For purposes of sampling, it has been assumed that the data will be normally distributed; however, this assumption will be checked and confirmed during the data quality assessment and the appropriate distribution applied to the data to obtain the 95\% UCL.

While radiological samples will be collected during closure activities to support waste management activities and future decontamination and dismantlement activities, the risk assessment will not address radionuclides. Residual radioactive contamination is not subject to HWMA/RCRA regulations and will be addressed under a separate regulatory authority.

\section{A-3.3.1 Estimate of Soil Exposure Concentrations}

Estimates of soil exposure concentrations will be based directly on the analytical data obtained during closure activities for the environmental media of concern. This assumes that source term concentrations remain constant over time and is conservative. 


\section{A-3.3.2 Estimate of Air Exposure Concentrations}

Estimates of air exposure concentrations due to emissions will be calculated as average values over the entire area and, therefore, will be the same regardless of location. The air exposure point concentrations will be estimated assuming the release mechanisms are fugitive dust emissions and volatilization. The following sections describe how these concentrations will be estimated.

A-3.3.2.1 Inhalation of Fugitive Dust. A respirable particulate (R) value will be used to estimate the contaminant concentration in the air $\left(\mathrm{C}_{\mathrm{AIR}}\right)$. The $\mathrm{R}$ value will be based on the respirable particulate emissions from wind erosion measured at the Idaho Nuclear Technology and Engineering Center (INTEC) (Mitchell 1994). The emissions will be assumed to be steady state with the concentration of the COCs not depleting with time. Equation (A-1) will be used to estimate this value.

$$
C_{\text {AIR }}=C F \times R \times C_{S O I L}
$$

where

$$
\begin{aligned}
& \mathrm{C}_{\mathrm{AIR}}=\text { contaminant concentration in the air }\left(\mathrm{mg} / \mathrm{m}^{3}\right) \\
& \mathrm{CF}=\text { conversion factor }(1 \mathrm{E}-09 \mathrm{~kg} / \mu \mathrm{g}) \\
& \mathrm{R}=\quad \text { respirable particulate matter }\left(14 \mu \mathrm{g} / \mathrm{m}^{3}\right) \text { (Mitchell 1994) (This value represents the } \\
& \text { 95\% UCL of the arithmetic mean of weekly airborne particulate matter concentration } \\
& \text { measured at the INTEC low volume air sampling station.) } \\
& \mathrm{C}_{\text {SOIL }}=\text { contaminant concentration in the soil }(\mathrm{mg} / \mathrm{kg}) \text {. }
\end{aligned}
$$

A-3.3.2.2 Inhalation of Volatiles. Appropriate air emission models will be used to predict volatile contaminant exposure concentrations in the air.

\section{A-3.4 Development of Chemical Intakes}

Route-specific exposures or intakes will be quantified through the use of standard intake equations, site-specific or default exposure parameters, and exposure point concentrations (as defined in Section A-3.3). Each chemical intake equation (EPA 1989, 2001a) that will be used along with a description of the associated exposure parameters for each scenario is given in Figures A-2 through A-5. In general, site-specific parameters will be used in the intake equations, where available. Where such information is not available, default EPA parameters will be used. 
$\operatorname{Intake}(\mathrm{mg} / \mathrm{kg}-$ day $)=\mathrm{C}_{\text {soil }} \times\left[\frac{(\mathrm{IR} \times \mathrm{FI} \times \mathrm{EF} \times \mathrm{ED}) \times \mathrm{CF}}{\mathrm{BW} \times \mathrm{AT}}\right]$

where

$\begin{array}{lll}\mathrm{C}_{\text {soil }} & = & \text { contaminant concentration in the soil }(\mathrm{mg} / \mathrm{kg} \text { based on } 95 \% \mathrm{UCL}) \\ \mathrm{IR} & = & \text { ingestion rate }(50 \mathrm{mg} / \mathrm{d}) \\ \mathrm{FI} & = & \text { fraction ingested }(1) \\ \mathrm{EF} & = & \text { exposure frequency }(200 \mathrm{~d} / \mathrm{yr})^{\mathrm{e}} \\ \mathrm{ED} & = & \text { exposure duration }(25 \mathrm{yr}) \\ \mathrm{CF} & = & \text { conversion factor }\left(10^{-6} \mathrm{~kg} / \mathrm{mg}\right) \\ \mathrm{BW} & = & \text { body weight }(70 \mathrm{~kg}) \\ \mathrm{AT} & = & \text { averaging time }(25,550 \mathrm{~d} \text { for carcinogenic, } 9,125 \mathrm{~d} \text { for noncarcinogenic }) .\end{array}$

Figure A-2. Soil ingestion chemical intake parameters. ${ }^{\mathrm{f}}$

e. Exposure frequency is based on four days per week (at 10 hours per day) for 50 weeks per year.

f. Values shown are default values for the INL Site unless otherwise noted. 


$$
\mathrm{AD}=\frac{\mathrm{C}_{\text {soil }} \times \mathrm{SA} \times \mathrm{AF} \times \mathrm{ABS} \times \mathrm{EF} \times \mathrm{ED} \times \mathrm{CF}}{\mathrm{BW} \times \mathrm{AT}}
$$

where
$\mathrm{AD}=$ absorbed dose $(\mathrm{mg} / \mathrm{kg}-\mathrm{d})$
Csoil $=$ contaminant concentration in the soil ( $\mathrm{mg} / \mathrm{kg}$ based on $95 \%$ UCL)
$\mathrm{SA}=\quad$ skin surface area available for contact $\left(3,300 \mathrm{~cm}^{2} /\right.$ event) (EPA 2001b)
$\mathrm{AF}=\quad$ soil to skin adherence factor $\left(0.2 \mathrm{mg} / \mathrm{cm}^{2}\right)$ (EPA 2001b)
$\mathrm{ABS}=$ absorption factor (unitless)
$\mathrm{EF} \quad=\quad$ exposure frequency $(200 \text { events/yr })^{\mathrm{g}}$
$\mathrm{ED} \quad=\quad$ exposure duration $(25 \mathrm{yr})$
$\mathrm{CF}=\quad$ conversion factor $(10-6 \mathrm{~kg} / \mathrm{mg})$
BW $\quad=\quad$ body weight $(70 \mathrm{~kg})$
AT $=$ averaging time (25,550 d for carcinogenic, $9,125 \mathrm{~d}$ for noncarcinogenic).

Figure A-3. Dermal absorption parameters. ${ }^{\mathrm{h}}$

g. Exposure frequency is based on one event per day, four days per week, 50 weeks per year.

h. Values shown are default values for the INL Site unless otherwise noted. 


$$
\operatorname{Intake}(\mathrm{mg} / \mathrm{kg}-\mathrm{d})=\frac{\mathrm{Cair} \times \mathrm{IR} \times \mathrm{ET} \times \mathrm{EF} \times \mathrm{ED} \times \mathrm{CF}}{\mathrm{BW} \times \mathrm{AT}}
$$

where

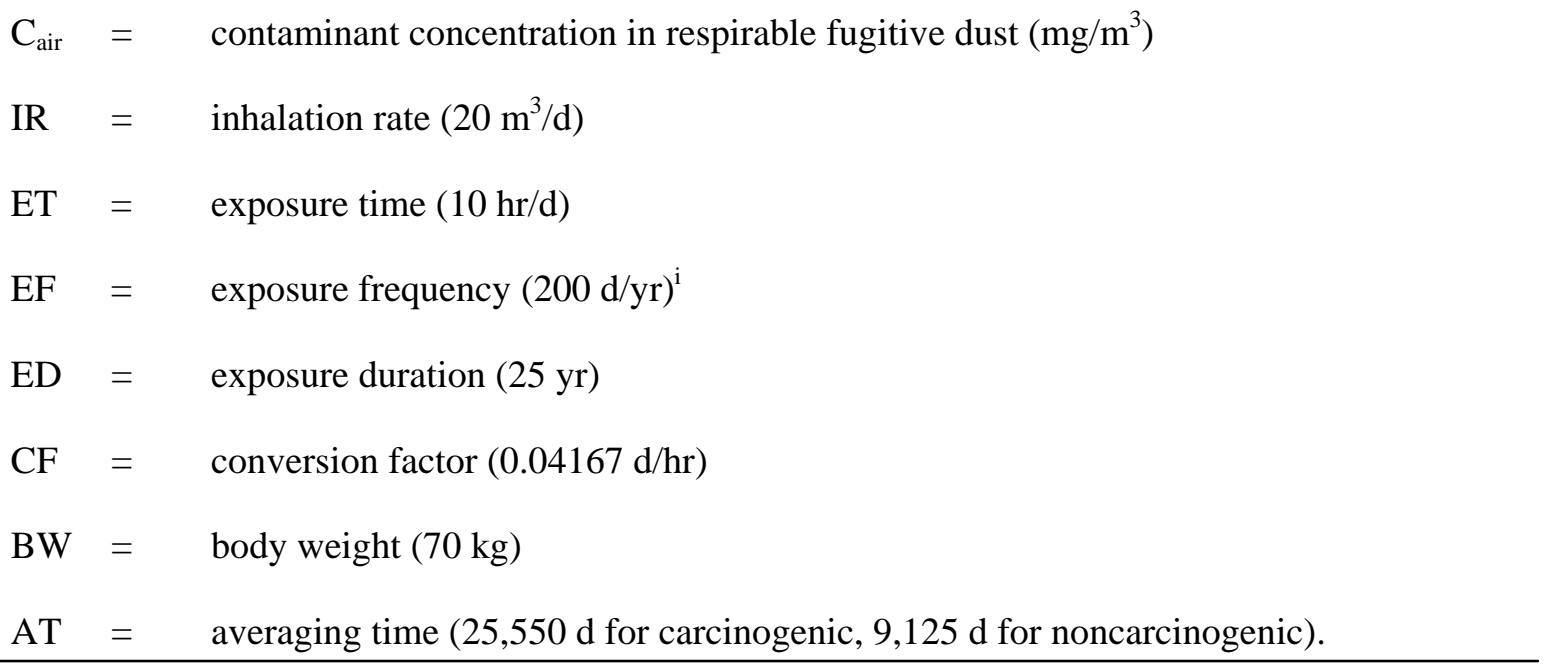

Figure A-4. Inhalation of fugitive dust intake parameters. ${ }^{j}$

i. Exposure frequency is based on four days per week (at 10 hours per day) for 50 weeks per year.

j. Values shown are default values for the INL Site unless otherwise noted. 
$\operatorname{Intake}(\mathrm{mg} / \mathrm{kg}-\mathrm{d})=\frac{\mathrm{C}_{\text {air }} \times \mathrm{IR} \times \mathrm{ET} \times \mathrm{EF} \times \mathrm{ED} \times \mathrm{CF}}{\mathrm{BW} \times \mathrm{AT}}$

where

$\mathrm{C}_{\mathrm{air}}=$ volatile contaminant concentration in the air $\left(\mathrm{mg} / \mathrm{m}^{3}\right)$

IR $=$ inhalation rate $\left(20 \mathrm{~m}^{3} / \mathrm{d}\right)$

$\mathrm{ET}=$ exposure time $(10 \mathrm{hr} / \mathrm{d})$

$\mathrm{EF} \quad=\quad$ exposure frequency $(200 \mathrm{~d} / \mathrm{yr})^{\mathrm{k}}$

$\mathrm{ED}=$ exposure duration $(25 \mathrm{yr})$

$\mathrm{CF}=$ conversion factor $(0.04167 \mathrm{~d} / \mathrm{hr})$

$\mathrm{BW}=$ body weight $(70 \mathrm{~kg})$

AT $=$ averaging time (25,550 $\mathrm{d}$ for carcinogenic, $9,125 \mathrm{~d}$ for noncarcinogenic).

Figure A-5. Inhalation of volatiles intake parameters. ${ }^{1}$

k. Exposure frequency is based on four days per week (at 10 hours per day) for 50 weeks per year.

l. Values shown are default values for the INL Site unless otherwise noted. 


\section{A-4. TOXICITY ASSESSMENT}

Toxicity values will be used to characterize risk for the COCs. Consistent with the Risk Assessment Guidance for Superfund (EPA 1989, 2001a), the toxicity information will be summarized for two categories of potential effects: carcinogens and noncarcinogens. The toxicity values that will be used quantitatively in the risk assessment will be obtained from two major sources, IRIS (EPA 2003a) and EPA Region 9 Preliminary Remediation Goal Table (EPA 2003b).

\section{A-4.1 Carcinogens}

Potential carcinogenic risks will be expressed as an estimated probability that an individual might develop cancer from a lifetime exposure to a specific concentration of a contaminant. This probability is based on projected intakes and chemical-specific dose-response data called slope factors (SFs). Slope factors and the estimated daily intake of a compound, averaged over the 24-year exposure duration, will be used to estimate the incremental cancer risk of an occupational worker exposed to that contaminant.

The oral and inhalation SFs for the COCs will be compiled in a table, including the weight-of-evidence (carcinogen groups), source reference, and date. Slope factors will also be provided for the inhalation route as unit risks in units of “microgram per cubic meter" $\left(\mu \mathrm{g} / \mathrm{m}^{3}\right)$.

\section{A-4.2 Noncarcinogens}

Potential noncarcinogenic effects will be evaluated in the risk characterization by comparing daily intakes (calculated in the exposure assessment) with chronic Reference doses developed by the EPA. If the chronic daily intake is below the RfD then there should be no adverse effects. Conversely, if chronic daily intakes exceed the RfD, there is a potential that some adverse noncarcinogenic health effects might be observed in exposed individuals.

\section{A-5. RISK CHARACTERIZATION}

Risk characterization involves estimating the magnitude of the potential adverse effects of the COCs under study and summarizing risks to the receptor. Risk characterization combines the results of the exposure and toxicity assessments to provide numerical estimates of health risk. These estimates are for lifetime cancer risk and comparisons of exposure levels with RfDs for a given intake. The process of characterizing risk includes the following:

- Calculating and characterizing carcinogenic and noncarcinogenic effects

- Conducting uncertainty analysis.

To quantify the health risks, the intakes are first calculated for each COC for each applicable pathway and scenario. The specific intakes are then compared to the applicable chemical-specific toxicological data to determine health risks. The health risks from each COC will be calculated to first determine potential carcinogenic effects and secondly to determine potential noncarcinogenic effects. Each of these calculations is discussed in the following sections. 


\section{A-5.1 Determining Carcinogenic Effects}

Equation (A-2) will be used to determine carcinogenic effects by obtaining numerical estimates, (i.e., unitless probability) of lifetime cancer risks.

$$
R I S K=I N T A K E \times S F
$$

where

$$
\begin{array}{ll}
\text { RISK } & =\text { potential lifetime excess cancer risk (unitless) } \\
\text { INTAKE } & =\text { chemical intake }(\mathrm{mg} / \mathrm{kg}-\mathrm{d}) \\
\mathrm{SF} & =\text { slope factor }(\mathrm{mg} / \mathrm{kg}-\mathrm{d})^{-1} .
\end{array}
$$

Inhalation and oral ingestion SFs will be used with respective inhalation and ingestion intakes to estimate risks. Cancer risks will be summed separately across all potential chemical carcinogens in the risk assessment using the following equation:

$$
R_{I S K_{t}}=\sum R I S K_{i}
$$

where

$$
\begin{aligned}
& \text { RISK }_{\mathrm{t}} \quad=\text { total cancer risk, expressed as a unitless probability } \\
& \text { RISK }_{\mathrm{i}}=\text { risk estimate for the } \mathrm{i}^{\text {th }} \text { contaminant. }
\end{aligned}
$$

The excess cancer risk posed by the COCs will be determined by accounting for INL Site background concentrations of each contaminant, as summarized in Background Dose Equivalent Rates and Surficial Soil Metal and Radionuclide Concentrations for the Idaho National Engineering Laboratory (INEL 1995). The pathways and contaminants driving the risk will be noted in the site-specific risk assessment and will be accompanied by any necessary qualifying statements. The numerous conservative assumptions involved in the risk assessment methodology will be documented in the site-specific risk assessment.

\section{A-5.2 Determining Noncarcinogenic Effects}

Health risks associated with exposure to individual noncarcinogenic compounds will be determined by calculating HQs and summing the HQs to obtain a hazard index. The noncarcinogenic hazard quotient is the ratio of the intake or exposure level to the RfD as follows:

$$
H Q=\frac{I N T A K E}{R f D}
$$

where

$$
\begin{array}{ll}
\text { HQ } & =\text { noncarcinogen hazard quotient } \\
\text { INTAKE } & =\text { chemical intake }(\mathrm{mg} / \mathrm{kg}-\mathrm{d}) \\
\mathrm{RfD} & =\text { reference dose }(\mathrm{mg} / \mathrm{kg}-\mathrm{d}) .
\end{array}
$$


If the hazard quotient for any chemical exceeds one there may be concern for potential health effects. The hazard index is obtained by adding the HQs for each chemical across the exposure pathways. The hazard index will be calculated using Equation (A-5):

$$
H I=\sum \frac{E_{i}}{R f D_{i}} \quad \text { or } \quad H I=\sum H Q_{i}
$$

where

$$
\begin{array}{ll}
\mathrm{HI} & =\text { hazard index } \\
\mathrm{E}_{\mathrm{i}} & =\text { chemical intake for the } \mathrm{i}^{\text {th }} \text { toxicant }(\mathrm{mg} / \mathrm{kg}-\mathrm{d}) \\
\mathrm{RfD}_{\mathrm{i}} & =\text { reference dose for the } \mathrm{i}^{\text {th }} \text { toxicant }(\mathrm{mg} / \mathrm{kg}-\mathrm{d}) \\
\mathrm{HQ}_{\mathrm{i}} & =\text { noncarcinogen hazard quotient for the } \mathrm{i}^{\text {th }} \text { toxicant. }
\end{array}
$$

The excess noncarcinogenic hazard posed by the COCs will be determined by accounting for INL Site background concentrations of each contaminant, as summarized in Background Dose Equivalent Rates and Surficial Soil Metal and Radionuclide Concentrations for the Idaho National Engineering Laboratory (INEL 1995). The pathways and contaminants driving the hazard will be noted in the site-specific risk assessment and will be accompanied by any necessary qualifying statements. The numerous conservative assumptions involved in the risk assessment methodology will be documented in the site-specific risk assessment.

\section{A-6. UNCERTAINTY ANALYSIS}

There are many sources of uncertainty introduced during the risk assessment process. These emerge during all aspects of the process beginning with site field investigations and sampling and analysis through risk characterization. The various aspects within the different steps in the evaluation that may influence the outcome of the risk characterization will be documented in the site-specific risk assessment along with a qualitative evaluation of the likelihood for a particular feature to overestimate, or underestimate the results.

\section{A-7. REFERENCES}

40 CFR 265.111, 2005, “Closure performance standard,” Code of Federal Regulations, Office of the Federal Register, September 2005.

40 CFR 265.197, 2005, “Closure and post-closure care,” Code of Federal Regulations, Office of the Federal Register, September 2005.

52 FR 52, 1987, "Interim Status Standards for Owners and Operators of Hazardous Waste Treatment, Storage, and Disposal Facilities; Final Rule,” Federal Register, U.S. Environmental Protection Agency, pp. 8704-8709, March 19, 1987.

55 FR 46, 1990, “National Oil and Hazardous Substances Pollution Contingency Plan,” Federal Register, U.S. Environmental Protection Agency, pp. 8666-8673, March 8, 1990. 
55 FR 145, 1990, “Corrective Action for Solid Waste Management Units (SWMUs) at Hazardous Waste Management Facilities,” Federal Register, U.S. Environmental Protection Agency, pp. 30798, July 27, 1990.

61 FR 85, 1996, “Corrective Action for Releases from Solid Waste Management Units at Hazardous Waste Management Facilities,” Federal Register, U.S. Environmental Protection Agency, pp. 19432-19464, May 1, 1996.

Cotsworth, E., Acting Director Office of Solid Waste, to RCRA Senior Policy Advisors Regions I - X, “Risk-Based Clean Closure,” March 16, 1998, RPC No. 03/16/98-1, RCRA Online No. 14174.

DOE-ID, 1995, Long-Term Land Use Future Scenario for the Idaho National Engineering Laboratory, DOE/ID-10440, August 1995.

EPA, 1989, Risk Assessment Guidance for Superfund (RAGS): Volume I - Human Health Evaluation Manual (HHEM) (Part A, Baseline Risk Assessment), Interim Final, Office of Emergency and Remedial Response, Washington, DC, EPA/540/1-89/002. NTIS PB90-155581, December 1989.

EPA, 2000, Guidance for Data Quality Assessment: Practical Methods for Data Analysis, EPA/600/R-96/084, QA00 Update, July 2000.

EPA, 2001a, Risk Assessment Guidance for Superfund (RAGS): Volume I - Human Health Evaluation Manual (HHEM) (Part D, Standardized Planning, Reporting and Review of Superfund Risk Assessments), Final, Office of Emergency and Remedial Response, Washington, DC, OSWER Directive 9285.7-47, December 2001.

EPA, 2001b, Risk Assessment Guidance for Superfund (RAGS), Volume I: Human Health Evaluation Manual (Part E, Supplemental Guidance for Dermal Risk Assessment) Interim, EPA/540/R/99/005, OSWER 9285.7-02EP, September 2001.

EPA, 2003a, Integrated Risk Information System (IRIS) Data Base, http://www.epa.gov/iris/index.html, Web page updated April 25, 2003, Web page visited June 3, 2003.

EPA, 2003b, EPA Region 9 Preliminary Remediation Goals, http://www.epa.gov/Region9/waste/sfund/prg/index.htm, Web page updated June 3, 2003, Web page visited June 3, 2003.

ICP, 2005, Characterization Summary Report for Operable Unit 3-13, Group 7, VES-SFE-20 Hot Waste System at INTEC, ICP/EXT-05-00993, Rev. 0, Idaho National Laboratory, Idaho Cleanup Project, September 2005.

IDAPA 58.01.05.009, 2005, "Interim Status Standards for Owners and Operators of Hazardous Waste Treatment, Storage and Disposal Facilities,” Idaho Administrative Procedures Act, Idaho Department of Environmental Quality, April 6, 2005.

INEEL, 2000, HWMA/RCRA Less Than 90-day Generator Closure Report for the VES-SFE-126, INEEL/EXT-2000-00582, Idaho National Engineering and Environmental Laboratory, May 2000.

INEEL, 2005, Comprehensive Facility \& Land Use Plan, http://cflup.inel.gov, Idaho National Engineering and Environmental Laboratory, Web page visited November 1, 2005. 
INEL, 1995, Background Dose Equivalent Rates and Surficial Soil Metal and Radionuclide Concentrations for the Idaho National Engineering Laboratory, INEL-94/0250, Rev. 0, February 1995.

Mitchell, R. G., 1994, The Idaho National Engineering Laboratory Site Environmental Report for Calendar Year 1993, Foundation-002, July 1994. 